DOI: 10.23928/foldt.kozl.2021.151.1.79

\title{
A geotermikus energia kutatása és hasznosítása Magyarországon az elmúlt 150 év tükrében
}

\begin{abstract}
Mottó: „Egy baja lévén, - gyógyvizének mennyisége ugyanis az igényeknek meg nem felelvén, fel lettem még 1867-ben és újból a legutóbbi időben a nagyméltóságu vallás-és közoktatás minister úr által szólitva véleményt adni, mi módon lenne ezen bajnak orvoslása eszközölhetö? Ismételve 1867-ben adott véleményemre hivatkozván, megbizattam az általam javaslatba hozott munkálatok keresztülvitelével, melyekröl a következökben szólani szerencsém leend." (ZsIGMONDY 1874)
\end{abstract}

\author{
SZANYi János ${ }^{1}$, NÁdOR Annamária² ${ }^{2}$ MADARÁsZ Tamás ${ }^{3}$
}

${ }^{1}$ Szegedi Tudományegyetem, Ásványtani, Geokémiai és Kőzettani Tanszék, szanyi@iif.u-szeged.hu

${ }^{2}$ Magyar Bányászati és Földtani Szolgálat, nador.annamaria@mbfsz.gov.hu

${ }^{3}$ Miskolci Egyetem, Környezetgazdálkodási Intézet, hgmt@uni-miskolc.hu

\section{0 years of geothermal energy research and utilization in Hungary}

Abstract

The present paper discusses the main results of the Hungarian geothermal research and its milestones from the middle of 19th century. Tribute is paid to the esteemed pioneers, and then the discussion is divided into three major periods after the pioneering times:

1.) The pioneering times - This is the longest period of those considered here. It ranges from the first drilling of thermal exploration boreholes by Zsigmondy in the 1870s, through to the expansion of therapeutic and spa-wellness tourism and the widespread agricultural utilisation of geothermal energy up into the 1990s. In this era excellent Hungarian researchers and engineers were far ahead of the international trends and established the international reputation of the Hungarian geothermal sector. In this "period of ascent" some of the achievements included (i) the establishment of well-known and still used water-analytical methods (e.g. "Than" equivalent percentage) (ii) the first international balneological congress was organised (Budapest, 1936) (iii) a vast majority of the famous Hungarian medicinal and thermal water resources were explored and (iv) the major thermal groundwater flow systems (both in karstic and basinal areas) were recognized. The discovery of a rapidly growing number of thermal-water wells was partly due to intensive hydrocarbon exploration (transformation of barren hydrocarbon wells). This process led to the development of some famous "thermal water centres", such as that at Szentes. The latter is still internationally recognized as a casebook example of the direct use of geothermal energy.

2.) The Recent Past - This period includes the initial steps after the change of the political regime in Hungary (19891990) and it includes mainly spa developments (spa tourism doubled during this period) and the expanding use of geothermal energy in district heating systems. Notable advances include the Hódmezóvásárhely cascade system. This has been in operation since 1994 and has an 18 MWth capacity. More progress is represented by the establishment of two major geothermal district heating projects in Miskolc (capacity: 55 MWth) and Györ (capacity: $52 \mathrm{MWth}$ ), both of which target the basement carbonate reservoirs. With the growing number and capacity of district- and space heating projects, the question of reinjection became the focal point of research, especially into porous aquifers. A major step in deep geothermal exploration and exploitation was the introduction of the "concession system" in 2012. This system accelerated projects targeting combined heat and power production. Nevertheless, the first geothermal power plant in the Pannonian Basin was commissioned only in 2018. This is the small-scale (2.3 MWe) ORC plant in Tura, which has a target reservoir shallower than the $-2500 \mathrm{~m}$ concessional limit. All in all, this period is still considered to demonstrate the climax of geothermal developments in Hungary; after it, Hungary ceased to be the main promoter of progress on a European scale.

3.) Contemporary projects - The current situation in geothermal energy exploration and utilisation is represented by recently finished projects, or ongoing national and international ones in which Hungarian universities, research institutes and companies are involved. Furthermore, the central geographical position of Hungary within the Pannonian basin means it is of vital relevance in the exploration of transboundary geothermal energy resources. This is shown by the fact that several projects involving neighbouring countries have established joint databases, assessments and recommendations for the enhanced use of the rich geothermal assets in the Central European region. Frontier concepts and methods of combined heat, power and metal extraction have also been studied in international consortia. The pilot results of such consultation provide a firm basis for technological upscaling in the near future.

4.) Research priorities and frontiers - The latest research results have been introduced in the context of domestic and international research priorities. Some highly innovative projects address operational issues and, among others items, study various aspects of scaling which are strongly related to increasing the efficiency of reinjection into porous aquifers. Novel well-technologies, such as the use of lasers in enhancing permeabilities, have also been introduced. With regard to the future growth of the Hungarian geothermal sector, the present research period also highlights the still untapped potential. This is especially true with respect to direct use., where the current utilization is at least one magnitude below 
kontinensek alatt, a kéreg átlagosan 22-30 km, míg a litoszféra 50-80 km vastag (HoRvÁTH \& BADA 2006). Ezért a litoszféra alatti lassú áramlásban lévő, hőt szállító asztenoszféra közelebb van a felszínhez, mint a Föld más pontjain (az aktív vulkáni területektől eltekintve). Magyarországon a geotermikus gradiens értéke átlagosan $5^{\circ} \mathrm{C} / 100 \mathrm{~m}$, ami mintegy másfélszerese a világátlagnak A mért hőáramértékek is nagyok: $2001 \mathrm{db} 1 \mathrm{~km}$-nél mélyebb fúrásban meghatározott mérés átlaga $90 \mathrm{~mW} / \mathrm{m}^{2}$, a maximális értékek (120-140 $\mathrm{mW} / \mathrm{m}^{2}$ ) az ország D-i részén találhatók, míg a minimális értékek (20-40 mW/m²) a karsztvíz-beszivárgási területeken fordulnak elố (LENKEY et al. 2021), miközben az európai kontinens nagy részén $60 \mathrm{~mW} / \mathrm{m}^{2}$ az átlagérték (DövÉNYI \& HoRvÁTH 1988). A felszínen kb. $10^{\circ} \mathrm{C}$ a középhőmérséklet, $\mathrm{s}$ az említett geotermikus gradiens mellett $1 \mathrm{~km}$ mélységben átlagosan $60^{\circ} \mathrm{C}, 2 \mathrm{~km}$ mélységben pedig $110^{\circ} \mathrm{C}$ a közetek és a pórusaikban tárolt víz hômérséklete. Az ismert, jó vízvezető képződmények legnagyobb mélysége eléri a 2,5 km-t. Itt a hőmérséklet már a $130-150{ }^{\circ} \mathrm{C}$ is lehet (SZANYI et al. 2009, LENKEY et al. 2021). A hévízkutakban felfelé haladó víz azonban lehúl, ezért a felszínen a vízhőmérséklet ritkán haladja meg a $100{ }^{\circ} \mathrm{C}$-t. A felszín alatti hőmérsékletet - a hőáramhoz hasonlóan - nagyban befolyásolják a felszín alatti vízáramlások, a negyedidőszaki és neogén porózus vízadókban fơként a felsô 1-1,5 km-es mélységben, ugyanakkor a karsztosodott karbonátos medencealjzatban ez akár több km-es mélységben is számottevő lehet. Gőzelőfordulásokat csak néhány, kellően még nem megkutatott, nagy mélységú előfordulásból ismerünk. Magyarország kiváló geotermikus adottsága tehát alapvetően két tényezőnek köszönhető. Az egyik a világátlagot mintegy másfélszeresen meghaladó, felszín felé áramló nagy hőfluxus, a másik a jó vízadó képződmények jelenléte. Ezek az Alföldön, a Kisalföldön és a Dráva-medencében elsôsorban pannóniai korú sekélyvízi homokkövek, az ország más részein pedig a prekainozoos medencealjzat repedezett, olykor karsztosodott, többnyire mezozoikumi karbonátos képződményei. A Pannon-medencében két fő hidraulikus áramlási rendszer létezik, a felső hidrosztatikus és az alsó túlnyomásos rendszer (1. ábra). A Pannon-medence hévíztermeléssel leginkább érintett felső áramlási zónájában a felszín alatti vizek mozgása alapvetően a gravitáció által meghatározott (ERDÉLYI 1979, MARTON 1982, ALMÁsI 2001, TÓTH \& ALMÁSI 2001, MÁDL-SZŐNYI \& TóTH 2015). A medence morfológiája biztosítja a mély áramlási rendszerek létezéséhez szükséges potenciális energiát. A medence méretû áramlási rendszerek koncepciója szerint (TóTH 1963) már nemcsak a homok- vagy kavicsrétegek, hanem az ôket közbezáró, eddig vízzárónak tekintett rétegek is közegei az áramlásnak. Az 500 mm-körüli évi csapadék és a jó vízvezető porózus kőzetek nagy felszíni elterje-

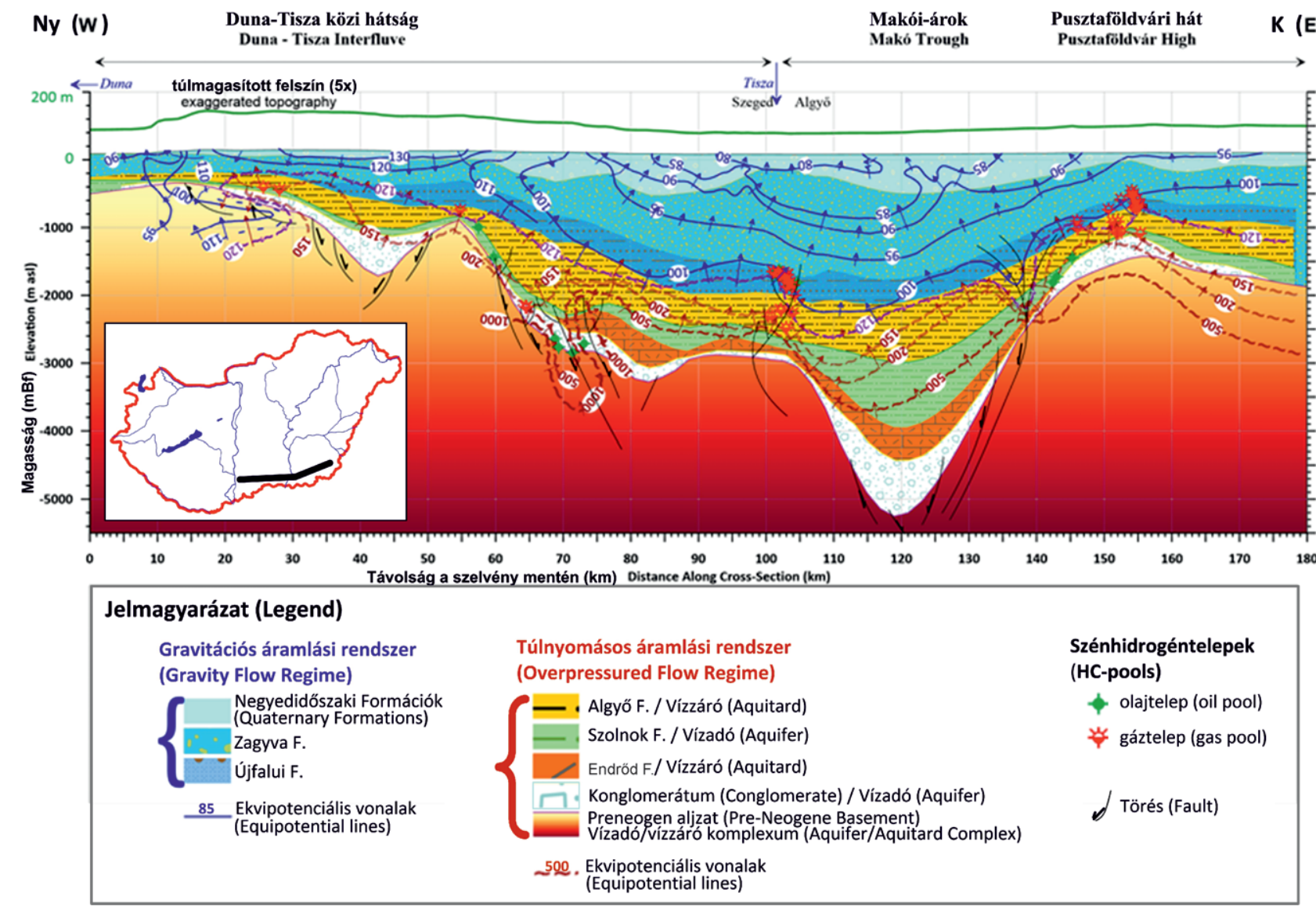

1. ábra. Sematikus hidrosztratigráfiai szelvény az Alföld déli részén keresztül, a szelvény helyének feltüntetésével (ALMÁsI \& SzANYI 2021 alapján) Figure 1. Schematic hydrostratigraphic profile across the Great Hungarian Plain with location of the section (modified after ALMÁSI \& SZANYI 2021). 
the sustainable use of the available geothermal resources. Current research also draws attention to one of the major bottlenecks connected to the geological risk and its mitigation: here, the gathering of knowledge with respect to the subsurface, and the systematic collection, assessment and publication of geoscientific data are key issues.

Taking the whole work into consideration, the delineation of single chapters is not sharply defined and they should be seen as thematic in nature. During the discussion, reference is made to geological, hydrogeological, geochemical and geophysical connections. However, these contexts are not elaborated in full but are discussed in separate papers of the commemorative issue of the "Földtani Közlöny".

Keywords: geothermal energy, research, utilization

Összefoglalás

Jelen tanulmányban a 150 évvel ezelőtt Zsigmondy Vilmossal induló magyarországi geotermikus kutatások legfőbb eredményeit, illetve a hazai geotermikus szektor fejlődésének fóbb lépéseit vázoljuk fel, megemlékezve a jeles elődökről. A tartalmi részt 4 időszakra osztottuk:

1.) A hőskor. A 19. sz. közepétől tart a rendszerváltásig. A leghosszabb időszakot fogja át, az elsô fúrásos hévízfeltárásoktól, a gyógy- és fürdőturizmus kiteljesedésén át a geotermikus energia mezőgazdasági hasznosításának elterjedéséig. Az az időszak, amikor a földtudomány kiváló hazai szakemberei, a nemzetközi trendek előtt járva, lehetővé tették a geotermikus energia széles körú hasznosítását, megalapozták a magyar geotermika nemzetközi elismerését. Ezt a felívelés korszakának tekintjük, ezért egyben tárgyaljuk.

2.) A közelmúlt. A rendszerváltást követő kezdeti lépések, melyek főleg fürdőfejlesztéseket és a geotermikus energia távhő célú fejlesztését jelentették. Ezek közül is kiemelkedik a hódmezővásárhelyi, miskolci és győri geotermikus távhőrendszer. A hódmezôvásárhelyi rendszer a komplex kaszkád hasznosítással és a homokkőbe történô sikeres és fenntartható visszasajtolási technológia alkalmazásával volt úttöró, míg a két utóbbi az $50 \mathrm{MW}_{\mathrm{th}}$-ot meghaladó beépített kapacitásával mutatott európai szinten is elismert példát. Ezen időszakban, a termálfürdő-fejlesztéseknek és új fürdők nyitásának köszönhetően, a termálturizmus megduplázódott. Ez már a zenit korszaka, 2003-ban még Európai Geotermikus Kongresszust rendeztek Szegeden, de már nem Magyarország volt Európában a fejlődés motorja.

3.) A jelen projektek. Az éppen befejezett vagy még futó jelentősebb geotermikus projekteken keresztül bemutatjuk a geotermikusenergia-hasznosítás jelenlegi magyarországi állapotát. Európai uniós csatlakozásunknak köszönhetően megnyílt a nemzetközi kutatási projektekben való részvétel lehetősége. Különösen a hazai egyetemek és kutatóhelyek de civil szervezetek is - csatlakozhattak az európai geotermikus kutatások főáramához. Az európai uniós források lehetővé tették a határon átnyúló kutatási projektek indítását, ennek köszönhetően a Kárpát-medence geotermikus viszonyait egységes szerkezetben, politikai határok nélkül lehet kutatni.

4.) A futó kutatások, jövőkép. Ismertetjük a hazai és a nemzetközi kutatásokhoz kapcsoló legújabb eredményeket, és felvázoljuk a jövőbeni kutatási irányokat, lehetséges helyünket a nemzetközi geotermikus piacon. Bemutatjuk, hogy - alkalmas szakpolitikával, a geotermikus adottságaink ismeretében - milyen mértéket érhet el a geotermikus energia hasznosítása Magyarországon a közeli jövőben.

Az egyes időszakok határai nem élesek, inkább tematikusak, így egy adott időszakban olykor későbbi tanulmányt is megemlítünk. Tárgyalásuk során röviden utalunk a földtani, hidrogeológiai, geokémiai és geofizikai kapcsolódási pontokra, de ezeket részletesen nem tárgyaljuk, a Földtani Közlöny aktuális ünnepi és rákövetkező évjáratában erről önálló tanulmányokat olvashatnak.

Tárgyszavak: geotermikus energia, kutatás, hasznositás

\section{Bevezetés}

Az elmúlt évszázadokban voltak boldog idők - mint a fenti esetben - mikor miniszterek karolták fel a hévízhasznosítás ügyét, és volt mikor börtön járt a nagy volumenú geotermikus fejlesztésekért, mint a Szentesi Termál Tsz elnökének 1972-ben (FöLDEÁKI 1972).

A Kárpát-medence több évezrede gyógy- és termálvizekben gazdag területként ismert. A Római Birodalom, a török hódoltság időszaka mind felívelő szakasza volt a termálvíz hasznosításának. Ezt követôen a fürdőkultúra háttérbe szorult, a gyógyvizek használata néhány főúr előjoga volt csupán. Ezekben az időszakokban jellemzően a felszínre szökő források hasznosítására volt lehetőség. A kiegyezés korában ZsigmONDY Vilmos és unokaöccse, ZsigMONDY Béla által továbbfejlesztett fúrástechnológia alkalmazása tette lehetôvé a nagyobb mélységú, akár 1000 m mélyről történô termálvíz termelését, a fürdőkultúra szélesebb körű elterjedését (ZsIGMONDY 1871). A társtudományoknak is köszönhetően a 20. században a geotermikusenergia-kutatás és -hasznosítás mintaországává váltunk Európában, elsősorban a hôhasznosítás terén. Bár átfogó képet kívánunk festeni, jelen tanulmány keretei nem teszik lehetôvé, hogy súlyának megfelelően szóljunk a geotermikus energia hasznosítását lehetôvé tevő, földtani, szerkezetföldtani, geofizikai, hidrogeológia, geokémiai és a geotermiához ezer ágon kapcsolódó szénhidrogén-kutatási - kőolajföldtani meghatározó tudományos eredményekrôl. Azonban a Földtani Közlöny ünnepi évadának cikkei ezekben a témákban is tájékozódási lehetőséget biztosítanak az érdeklődő olvasónak. Továbbá nem célunk Magyarország és tágabb térsége, a Kárpát-medence geotermikus adottságainak átfogó ismertetése - az utóbbi évtizedekben számos kiváló publikáció született e témában (KoRIM 1972, DövÉNYI \& HORVÁTH 1988, DövÉNYI et al. 2002, LENKEY et al. 2002, SZANYI \& KovÁCs 2010 , HoRvÁtH et al. 2015, NÁDOR 2019, LENKEY et al. 2021) -, ezért csak röviden szólunk róla.

A Pannon-medence középső miocénben történő megnyílása során a húzóerôk hatására Magyarországon a földkéreg, az egész litoszféra jelentôsen vékonyabb, mint általában a 
dése fenn tudja tartani a mély áramlási rendszereket és ezek mentén a vizek forgalmát. Ebből következően a kitermelt termálvíz döntően az üledék koránál fiatalabb, meteorikus eredetú víz. A hierarchikus áramlási rendszerek léte a Pannon-medencében azt jelenti, hogy az Alföld hajdani mocsarassága, mostani szikessége, feltörô belvizei, aszályos dombhátai, mélyből felszökő artézi vizei, jellegzetes növényei, geotermikus hôkincse, olaj- és gázmezôi mind összefüggésben vannak egymással. (ALMÁsı \& SZANYi 2021)

Végül meg kell jegyeznünk, bár szólunk a hőszivattyúk alkalmazásával kapcsolatos kutatásokról, cikkünk elsősorban a mélygeotermikus kutatásokra és hasznosítások bemutatására koncentrál.

\section{A höskor}

A hazai tudományos mélységi vízkutatás kezdetét ZsiGMONDY Vilmos tevékenységétől számítjuk, melyet az 1865ben megjelent „Bányatan, kiváló tekintettel a kőszénbányászatra" c. múve vezetett be. Ebben a szénkutatás mellett a mú utolsó fejezetében nagy részletességgel számol be a fúrási kutatáshoz használt eszközökről „A kutatás, fúrászat, s az artézi kutak" címmel (ZsigmONDY 1865). Első hévízkútjait Harkányban, a Margit-szigeten, majd 1868 és 1878 között a Városligetben mélyítette. Utóbbi helyen 970 m-es talpmélységú, $74{ }^{\circ} \mathrm{C}$-os vizet szolgáltató kútjával érte el a felsố triász vízadót (ZsIGMONDY 1879). A Városligeti kút a létesítésekor Európa második legmélyebb kútjának számított, és közel 150 év után is üzemképes.

A sikeres hévíztermelés az analitikai kémia felé fordította a figyelmet, melynek klasszikus területe az ásványvízvizsgálat volt. Ennek a tudományterületnek vált nemzetközi hírú kutatójává THAN Károly kémikus, egyetemi tanár, aki az ásvány- és gyógyvizek kémiai alkotóit már nem sókban, hanem ionokban adta meg. Módszerével nemcsak a víz jellege, hanem több ásványvíz ösz-szehasonlítása is elvégezhető volt (SZANYı et al. 2013). Kutatási eredményeiről 1864ben Marosvásárhelyen, a Magyar Orvosok és Természetvizsgálók vándorgyúlésén tartott előadást, mely csak 1890ben jelent meg nyomtatásban (THAN 1890). A harkányi I. sz. kút vize kémiai összetételének vizsgálatakor elsőként mutatta ki a „szénoxi-szulfidot”. Munkássága nyomán azóta is használjuk a Than-féle egyenérték százalékot a vegyelemzések értékelésénél, mely megadja, hogy egy meghatározott alkotórészből, oldott állapotban, egy liter víz mennyi mg egyenértéksúlyt tartalmaz (DoBos et al. 2013).

Az 1869-ben megalapított Magyar Királyi Földtani Intézet és az 1907-ben megalakult, később EÖTVÖs Lorándról elnevezett Geofizikai Intézet kutatói, így EöTvös Loránd, Lóczy Lajos, Schafarzik Ferenc, SüMEghy József és PÁVAI-VAJNA Ferenc munkásságának volt köszönhetô, hogy 1936-ban Budapesten rendezték meg az első nemzetközi Balneológiai Kongresszust. Közülük PÁvAI-VAJNA Ferencnek több jelentős gyógy-és hévizünk, például Hajdúszoboszló, Karcag, Debrecen és Szolnok feltárását köszönhetjük. Ebben az időszakban hazánk kulcsszerepet játszott a gyógy- vizekkel kapcsolatos tudományos kutatásokban. 1937-ben Budapesten magyar kezdeményezésre megalakult a „Fédération Internationale de Stations Balnéaires, Climatiques et Maritimes", amely a késóbbi Fédération Internationale du Thermalisme et du Climatisme (Termál és Klíma Hasznosítás Nemzetközi Szövetsége) jogelődje. A szervezet székhelyéül Budapestet választották, elnöke és főtitkára is magyar volt (https://people.inf.elte.hu/madtaai/tortenet.html).

A budapesti termálkarszt forrásait elsôként VENDL Aladár rendszerezte, megfigyelésüket PAPP Ferenc folytatta és KESSLER Hubert a Vízügyi Tudományos Kutató Intézet (VITUKI) munkatársaként teljesítette ki (KESSLER 1956), aki Siklós-Harkány, Tata és Hévíz térségében is létesített termálkarsztvízszint észlelő fúrásokat (LORBERER 2004). A budapesti termálkarszt áramlási rendszereinek értelmezését ALFöLDI László vezetésével mások mellett LIEBE Pál és LORBERER Árpád végezték a termális konvekció felismerésével („,karélyos áramlás”) (ALFöLDI 1965, 1981).

A bükki termálkarszt fúrásokkal való feltárása 1870-ben kezdődött meg Egerben, és a mai napig is tart csaknem a teljes Bükk-térségben, bár a hegység peremi része a langyos és meleg vizú források miatt már évszázadok óta ismert volt (DomBI 1766). Felhasználásuk alapvetôen fürdési céllal történt, de a gyógyászat és a rekreáció is megjelent célként, mint például Eger, Kács(tapolca), Miskolctapolca (egykor Görömbölytapolca vagy Tapolcafürdő), Diósgyőr(tapolca). (A tapolca szó egyébként a délszláv toplice szóból ered, jelentése meleg víz.) Egerben 1926-ban létesítettek új kutat, Bükkszéken (1938) és Mezőkövesden (1939) meddő szénhidrogénkutató fúrások hoztak termálkarsztvizet a felszínre. A II. világháború után Miskolcon (1953), Bogácson (1959), Sajóhídvégen és Egerszalókon (1961), majd Andornaktályán (1962, 2008, 2017) mélyítettek termálkarsztkutakat, esetenként többet is az adott területen az idő múlásával (LÉNÁRT 2019).

A zalai termálkarszt megismerése szorosan összefüggött a térségben zajló, az 1920-as években indult szénhidrogén-kutatással (KôRÖSSY 1988, KovÁcs 2018), a nemzetközileg is népszerú zalai gyógy- és termálfürdők (Zalakaros, Zalaegerszeg, Zalaszentgót, Kehidakustány) kiépülésével, illetve a Hévízi-tó és a Dunántúli-középhegység bányászati karsztvízszint süllyedése kapcsolatának vizsgálatával (ALFÖLDI \& KAPOLYI 2007, TóTH 2017).

Az Alföld hévíztároló rendszerei utánpótlódási mechanizmusának komplex szemléletû vizsgálatát ERDÉLYI Mihálynak köszönhetjük, aki a Tóth-féle egység-medence koncepciót felhasználva (Тóтн 1963) igazolta az egyes vízadók közötti hidraulikai kapcsolatot (ERDÉLYi 1979, 1985).

A hévíz komplex hasznosítása első helyszínének Hajdúszoboszlót tekintjük, ahol 1925-ben egy 1019 m mély, meddő szénhidrogén-kutatófúrás $70{ }^{\circ} \mathrm{C}$ hőmérsékletû hévizet tárt fel. Ezt nemcsak a gyógyfürdőben hasznosították, hanem palackozták, továbbá üvegházak fútésére, míg a kitermelt gázt vasúti kocsik világítására és áramfejlesztésre is használták. A II. világháborút követően BoLDIZSÁr Tibornak, a Miskolci Egyetem professzorának köszönhetően a magyarországi geotermikus kutatások ismét a nemzetközi érdeklődés homlokterébe kerültek. Munkássága eredmé- 
nye, hogy a geotermika tudománya a felsőfokú oktatás részévé vált (BOLDIZsÁR \& Gózon 1965), illetve az ő nevéhez füződik Magyarország első hőáramsûrûség térképének az elkészítése is (BOLDIZSÁr 1967). Ebben az időben a termálkutak létesítése jórészt a szénhidrogén-kutatáshoz kapcsolódott. Többnyire a szénhidrogénre meddő, de megfelelő hőfokú termálvizet szolgáltató, településekhez közeli kutatófúrásokat képezték ki termálkúttá. Az első kaszkád jellegú hasznosítást (több lépcsóben, különböző hóhasznosítási módokat egymás után kapcsolnak a kinyerhető hömennyiség maximalizálása érdekében) a szentesi kórházban az 1958-ban mélyített 1736 m mély, 1700 l/min $79^{\circ} \mathrm{C}$ hőmérsékletû hévízzel valósították meg. Kezdetben kommunális fútésre, használati meleg víz elóállításra, balneológiai hasznosításra, majd később a mezőgazdaságban üvegházak fútésére is sor került (SZANYI et al. 2013). Szentes térsége aztán a geotermikus energia agrárhasznosításának központjává vált. Mára mintegy 40 üzemelő termálkút van a város 10 km-es sugarú körzetében, mind pannóniai sekélyvízi deltaeredetú homokkövekre szűrőzve.

Az előbb leírt folyamat fordítottja játszódott le Tápén 1965-ben. A helyi termelőszövetkezet hévízellátására DoBOS Irma tûzte ki a kút helyét, de víz helyett olajat találtak. Annak ellenére, hogy a térségben a szénhidrogén-kutatás már folyamatban volt, ez volt az elsô produktív kút az algyői szénhidrogénmezőben. A sors fintora, hogy míg a jeles elődökről, akik olaj helyett termálvizet találtak, számos településen szoborral emlékeztek meg, addig a víz helyett olajat fakasztó nevét még tábla sem őrzi...

A fúrások gyarapodó számát látva a második világháborút követően VITÁLIS Sándor indította el a mélyfúrású kutak nyilvántartásba vételét, amit KoRIM Kálmán folytatott és URBANCSEK János teljesített ki a hévízkútkataszterrel (BÉLTEKY et al. 1965, 1971, 1977). Az első korszerú, számítógépes adatbázis létrehozása DövÉNYI Péter nevéhez füződik, aki gyakorlati elemző munkájával nagyban segítette Magyarország geotermikus viszonyainak megismerését (DövÉNYI \& HoRVÁTH 1988, DövÉNYI 1994). Az azóta is fejlődő adatbázis párját ritkító, óriási kincs, alapját képezi a fenntartható geotermikus energiahasznosítás fejlesztésének. A Magyar Bányászati és Földtani Szolgálat - a 2014-ben megszüntetett VITUKI adattárát is átvéve - 2017 óta üzemelteti a központi vízföldtani adattárat, illetve vezeti az országos hévízkútkatasztert (https://mbfsz.gov.hu/vizfoldtani-adattar).

Fontos megemlíteni a sekély geotermiához kapcsolódó hőszivattyús hasznosításokat, ezek alapja a HELLER László által 1948-ban kidolgozott kompresszoros hôszivattyú technológia. Érdekesség, hogy HeLLER László egyetemi tanulmányait Svájcban, az ETH-Zürich-en végezte, mint RYBACH László 1956-ot követóen, aki az 1970-es években elsők között végzett számításokat a geotermikus energia hőszivatytyús hasznosíthatóságáról, és szerkesztette STEGENA Lajossal a geotermikus energia különböző hasznosítási módjait tárgyaló nemzetközi tanulmányt (RYBACH \& STEGENA 1979). RYBACH professzor élete ezt követôen összefonódott a geotermikával, kutatási területe az alacsony hőmérsékletú hasznosítástól az áramtermelésig a teljes spektrumot átfogja
(RYBACH 2019). Szakmai elismertsége a Nemzetközi Geotermikus Szövetség (International Geothermal Association) elnökévé emelte.

\section{A közelmúlt}

A geotermia-szektor rendszerváltást követő leglátványosabb növekedését a gyógy- és termálfürdők fejlesztése, új fürdők létesítése eredményezte. A fejlődés ütemét a mórahalmi fürdő fejlődésén keresztül mutatjuk be, amely jól példázza a növekedést. Az 1960-ban a községi tanács által pannóniai sekélyvízi, deltaeredetú homokkő-rezervoárba fúratott 660 m mélységú, 39,5 ${ }^{\circ} \mathrm{C}$-os vizet szolgáltató kút kezdetben egy gyógymedencével és gyermekpancsolóval rendelkezett. A tervszerú fejlesztések 1999-ben kezdődtek meg a fóépület átépítésével, új beltéri medencék létesítésével. A fürdőt 2006-ban regionális jelentőségú gyógyfürdővé minősítették. 2010-ben $3000 \mathrm{~m}^{2}$-es fedett gyermekfürdőt, wellness részleget és kistérségi egészségügyi ellátóhelyet hoztak létre. Ekkor már 1 kút helyett 4 termálkút szolgáltatta a vizet, és komplex módon fútési célra is hasznosították a termálhőt. Az utolsó nagy fejlesztés során az elfolyó termálvíz hőjét hőszivattyúval hasznosították a fürdő és a város középületeinek fútésére és használati meleg víz biztosítására. A medencék száma 21-re nőtt. Az alig 6 ezer fős településen a 2000-ben nyilvántartott 30 ezres éves látogatószám 2011-re 400 ezer fölé emelkedett (KIS \& FöRGETEG 2017). Mára más megújuló energiaforrásokat is kombináló, integrált távhőrendszer épült ki, ahol az 1100-1300 m közötti mélységből szármató $62-69{ }^{\circ} \mathrm{C}-0 s$ víz hasznosítás után részlegesen viszszasajtolásra kerül (SZANYI et al. 2013). A jelentôs fejlesztéseknek köszönhetően ma Magyarországon 162 termálfürdővel rendelkezünk, ez a szám 2010-ben 104 volt. A termálfürdôk éves látogatószáma mára 30 millió körüli (KSH 2010).

A fütési célú közvetlen hőhasznosítás tekintetében Magyarország hosszú évek óta Európa élmezőnyében van (Franciaország, Németország és Izland mögött a 4. helyen) (EGEC 2017, 2018, 2019), köszönhetően a geotermikus távés városfütési rendszereknek (ez utóbbi esetben külön az e célból kiépített termálvízvezeték köti össze a fútési körbe bekapcsolt középületeket). A rendszerek közül a legrégebbi az 1958-ban átadott szentesi rendszer. Az 1990-es évek végétől, de különösen a 2000-es évek elején egymás után épültek az újabb geotermikus fútési rendszerek, ezek közül is példaértékú az 1994 óta üzemelő, jelenleg 18 MW th kapacitású hódmezővásárhelyi geotermikus távfütési rendszer (KuRUNCZI 2008, ÁdOK 2012). (Termálkutak esetében beszélhetünk termikus, azaz hôteljesítményröl és elektromos teljesítményrốl, elóbbi esetben a mértékegységet jelölö megawatt jel után alsó indexként ,th”, míg elektromos teljesitmény esetén „e” indexet használunk. Mivel a höenergia elektromos árammá csak nagy veszteséggel alakítható, így az adott kút elektromos teljesítménye mindig lényegesen kisebb, mint a hốteljesítménye). A szentesi rendszerhez hasonlóan ez is a pannóniai sekélyvízi, deltaeredetû homokkövet szúrőzi 3 db 1800-2300 m közötti, 80-86 C-os termeló 


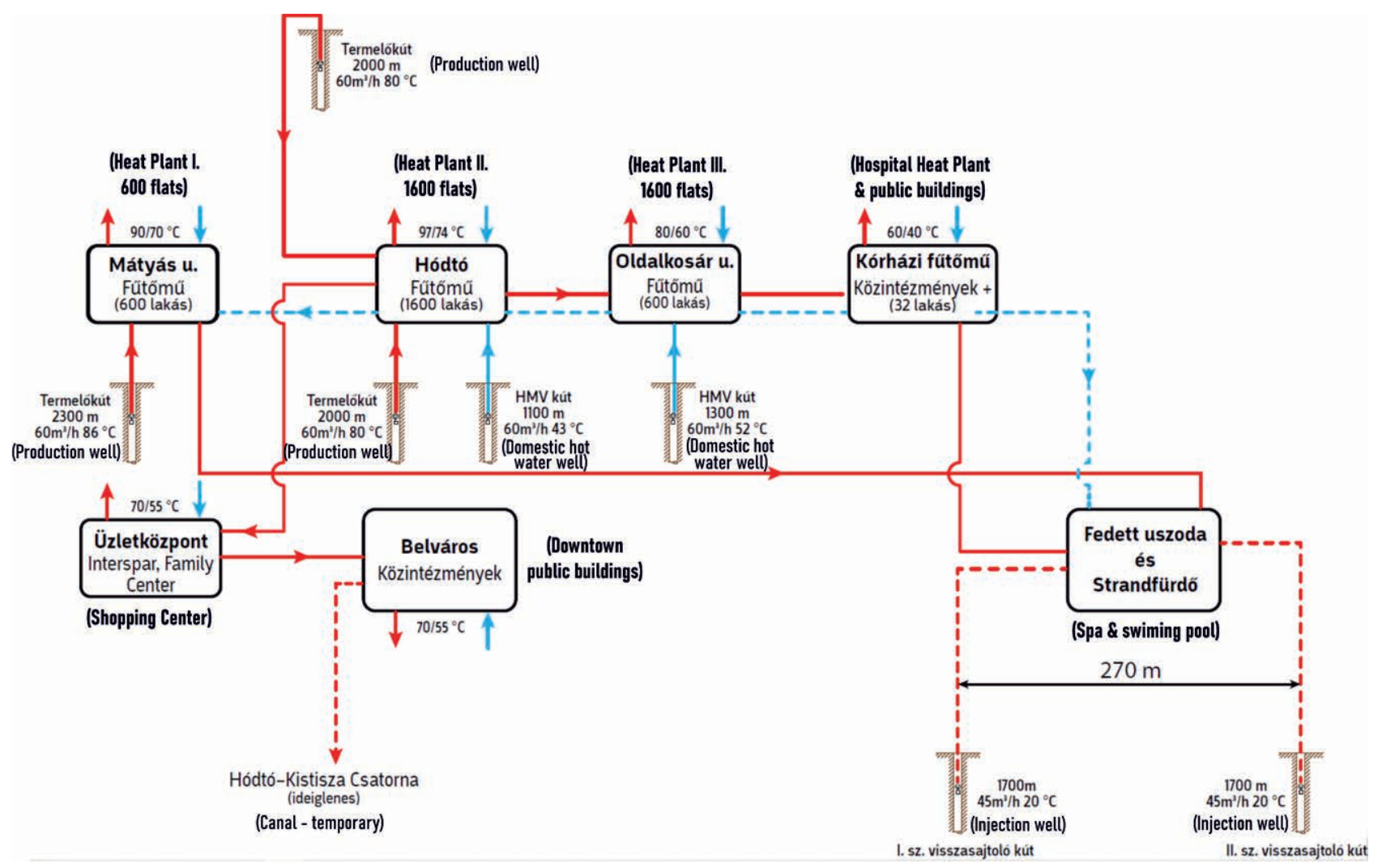

2. ábra. A hódmezővásárhelyi távhőrendszer elemei (SZANYI et al. 2013)

Figure 2. The geothermal system of Hódmezövásárhely (SZANYI et al. 2013)

és $2 \mathrm{db}$ visszasajtoló kúttal, míg a használati meleg vizet 2 sekélyebb, 1000-1300 m között megnyitott, 43-52 ${ }^{\circ} \mathrm{C}$-os vizet adó kút szolgáltatja. A pannóniai sekélyvízi homokkőre települt rendszerek közül ez az első, ahol kaszkád hasznosítást követően (2. ábra) sikeresen sajtolták vissza a lefütött termálvizet kutanként átlagosan 40 m³/órás ütemmel, a visszasajtolás kulcsa a felszíni szúrőrendszer (SZANYI et al. 2013).

A pannóniai porózus homokkőre telepített rendszerek mellett nagy szerepe van a mezozoos karbonátos rezervoárokat megcsapoló geotermikus fütési rendszereknek, így például a folyamatosan bővülő, 1993-ban átadott veresegyházi rendszernek, mely a fejlesztéseket követően 3 termelő és 1 visszasajtoló kúttal üzemel 12,1 $\mathrm{MW}_{\text {th }}$ hôteljesítménynyel (SZITA 2014, SzőKE 2016). A geotermiával üzemelő, jelenleg legnagyobb miskolci távhőrendszert 2013-ban adták át, beépített kapacitása $55 \mathrm{MW}_{\text {th }}$. A rendszer 2 termelő és 3 visszasajtoló kúttal az 1500-2300 m mélységben található triász karbonátos rezervoárból származó $87-102{ }^{\circ} \mathrm{C}$-os termálvízzel fúti az avasi lakótelepet, valamint biztosítja a miskolci belváros és a Miskolci Egyetem fútési és használati meleg víz hőigényének egy részét. Hasonlóan nagyszabású geotermikus fútési projekt a 2015-ben átadott 3 db termelő és $2 \mathrm{db}$ visszasajtoló kútból álló $52 \mathrm{MW}_{\mathrm{th}}$-os győri rendszer, amely ugyancsak repedezett-karsztos triász rezervoárból, 2500 m körüli mélységből, $100^{\circ} \mathrm{C}$-ot meghaladó hômérsékletû, 300-400 m³\%óra hozamú forró vizet tár fel a városi távfútés, illetve egy jelentős ipari felhasználó számára. A miskolci és győri két rendszer együtt közel felét teszi ki az ösz- szes hazai távfútési célú geotermikus energiatermelésnek (NÁDOR et al. 2019a).

Emellett egyre több helyen - ahol a termálvizet fürdési / gyógyászati célra használták - kezdték meg a kitermelt víz hőenergiáját a fürdőépületek vagy a közvetlenül csatlakozó épületkomplexumok fütésére is felhasználni. Az ilyen egyedi épületfútés hozzávetôleges becslések szerint jelenleg több mint 40 településen érhetô el, és 77,2 MW th beépített kapacitást és 83,1 GWh ${ }_{\mathrm{th}}$ éves termelést jelent. 2018 végén a geotermikus távfütés 22 településen volt elérhetô, amelyek összesen kb. 223,36 $\mathrm{MW}_{\text {th }}$ beépített kapacitást és $635,66 \mathrm{GWh}_{\text {th }}$ (2,3 PJ) éves termelést jelentettek (NÁDOR et al. 2019a).

A geotermikus fútés kapcsán külön kell szólnunk a használt termálvizek visszasajtolásáról. A termálvíz visszasajtolása alapvetően két ok miatt szükséges: a rétegnyomáscsökkenés ellensúlyozására, illetve a felszíni befogadók szennyeződésének elkerülésére. A visszasajtolás iránti igény már a geotermikus rezervoárok hasznosítása előtt megszületett. Az olajiparban a pannóniai korú homokkövekbe közel 50 éve sajtolnak vissza vizet a másodlagos szénhidrogéntermelés érdekében igen magas, olykor 100 bar-t meghaladó nyomáson. Ez a technológia a termálvizek esetében roppant gazdaságtalan és hosszú távon nem fenntartható (SZANYI et al. 2013). Az OKGT a Nagyalföldi Kőolajfeltáró üzemben 1978-ban 3 meddő szénhidrogénkutat perforálással hévízkúttá képezett ki, és a kutakon visszasajtolási kísérletet végzett. A tesztvizsgálatok szerint 3 hónap üzemelés után a visszasajtoló kút nyelőképessége jelentôsen lecsökkent, amit 
döntő részben a kút homokkal való feltöltődése okozott, de a csökkenésben szerepe volt a pórustorkok lebegőanyaggal való eltömődésének is (MEGYERY 1974). Ezt követôen többféle kísérlet zajlott, például kettős kiképzésû termelő-viszszasajtoló kúttal Szentesen (középsố csố termel, mellette a gyưrûs térben, a termelt réteg feletti rétegbe visszasajtol), azonban a kezdeti visszasajtolási kísérletek sikertelennek bizonyultak. Az első gazdaságosan múködő visszasajtoló kút 1998-ban épült meg Hódmezővásárhelyen. Azóta ebbe a kútba több mint 2,6 millió $\mathrm{m}^{3}$ vizet sajtoltak vissza 2-5 bar nyomáson (SZANYI et al. 2013). Mivel a fenntartható geotermikus energia termelése csak visszasajtolással lehetséges, számos kutatás folyik e-tárgyban, melyről az utolsó fejezetben szólunk.

Ezen időszak projektjei zömmel privát vállalkozások tervei alapján készültek, melyek jelentős részben az elődök által felhalmozott adatokra és információkra épültek. Ebben a folyamatban fontos szerepet játszott a két geotermikus szakmai szervezet, a Magyar Geotermális Egyesület és a Magyar Termálenergia Társaság, melyek a projektgeneráláson túl a befektetők - zömmel önkormányzatok - és a hatóságok között közvetítő szerepet is játszottak. Új színt hozott a Szegedi Tudományegyetem spin-off cégeként induló szervezet (olyan új, magas technológiai szintü, tudásintenzív vállalkozást értünk rajta, amely szellemi tókéjét valamilyen formában egy egyetemtól, vagy más közfinanszírozású kutatóintézettól eredezteti), ahol a kutatás közvetlenül összekapcsolódott a projekttervezéssel, és a Dél-alföldi régió számos településén tervezték meg a visszasajtolással üzemelő geotermikus távhőrendszereket (SZANYI et al. 2013). Ennek legjobb példája a Szegedi Tudományegyetem 2015-ben létesített újszegedi- és belvárosi termálrendszere 1-1 termelő és 2-2 visz-szasajtoló kúttal. A termelő kutak 1950 m-es, míg a visszasajtoló kutak 1750 és 1300 m-es talpmélységgel mélyültek. A rendszerek 4,5 $\mathrm{MW}_{\text {th }}$ teljesítményúek, $90^{\circ} \mathrm{C}$-os kifolyó víz hőmérséklettel, 1200 1/perc átlaghozammal (ÁDÁM et al. 2019).

Természetesen a kapcsolódó alapkutatások új eredményei, mint például a szerkezetföldtan, felszíni- és lyukgeofizika, hidrogeológia eredményei folyamatosan beépültek a projekttervekbe. Az Alföld áramlási rendszerének a hőmérséklet-eloszlásra gyakorolt hatásáról ALMÁsI készített vízés szénhidrogénkutak adatain alapuló dolgozatot (ALMÁsI 2001). A projektek köré szerveződő lokális kutatások mellett a kutatóhelyek főleg statikus és perspektivikus készletek országos léptékú becslésével, ezek módszertani kérdéseivel foglalkoztak (REZESSY et al. 2005, MÁDLNÉ-SzŐNYI 2006, Вовок \& Tо́тн 2010a). Ebben az időszakban készült el az Ásványvagyon-hasznosítási és Készletgazdálkodási Cselekvési Terv részeként a hazai geotermikus energiapotenciál becslése (ZILAHI-SEBESS et al. 2012), ami több későbbi szakpolitikai dokumentum megalapozó tanulmányaként szolgált. Ugyancsak fontos kiemelni a Miskolci Egyetemen а Вовок Elemér körül szerveződő geotermikus iskolát, amely a fluidumtermelés nélküli technológiák hasznosítási lehetôségeit is kutatta (Вовок 2012), és 2007ben elindították a geotermikus szakmérnök képzést.

Mivel Magyarországon a geotermikus energia hasznosí- tása gyakorlatilag hévíztermeléssel történik, így mindenképp meg kell említeni a termálvíz-gazdálkodás kérdéskörét. A Vízgyújtő-Gazdálkodási Tervek (VGT) alapelemei az ún. „víztestek”. A felszín alatti víztestek lehatárolása során többek között földtani (medencebeli, karszt, hegyvidéki), hômérsékleti (hideg $<30{ }^{\circ} \mathrm{C}$, termál $>30{ }^{\circ} \mathrm{C}$ ), hidrogeológiai (le- és feláramlási területek) szempontokat vettek figyelembe, amely alapján 15 termálkarsztvíztestet és 8 porózus termálvíztestet jelöltek ki (3. ábra). A Vizgyújtő Gazdálkodási Tervek során a viztesteket 6 évente minőségi és menynyiségi állapotértékelésnek vetik alá. A mennyiségi állapot tekintetében a VGT-2 a szabadbattyáni termálkarsztot gyenge, illetve a dél-alföldi porózus termálvíztestet jó állapotú, de romló kilátásúnak minősítette. Ez utóbbi szoros összefüggésben van a Dél-Alföld jelentős termálvízkivételeivel és a visszasajtolás hiányával (SZANYi 2015).

A geotermikus energia kutatásában és kitermelésében mérföldkövet jelentett a Bányászatról szóló 1993. évi XLVIII. törvény 2010-es módosítása, amely geotermikus energia vonatkozásában az egész ország területét a természetes felszíntől mért $2500 \mathrm{~m}$ alatti mélységben zárttá minősítette. Ebben a tartományban a geotermikus energia kutatását és kinyerését koncesszióhoz kötötte, amelyet a bányafelügyelet hatáskörébe rendelt. (Az e fölötti térrészből a geotermikus energia / termálvíz kitermelése továbbra is vízjogi engedély alapján végezhető tevékenység maradt). Ezzel egy, a bányászat és vízügy között sok éve tartó, elsősorban a hatáskörről és az engedélyeztetésről szóló szakmai egyeztetés végére került pont (SZANYI et al. 2009), ami azonban a 2500 m-es „mesterséges” mélységhatár tekintetében nem teljesen oszlatta el az aggályokat. A jogszabály-módosítás bevezette a koncessziót megelőzô ún. „,komplex érzékenységi és terhelhetőségi vizsgálat" (amelynek részleteit a 103/2011. VI. 29. kormányrendelet szabályozta), illetve a geotermikus védőidom fogalmát is. Ez utóbbi lehatárolása a zárt területen történő geotermikus energiakitermelés feltétele, és a bányafelügyelet jelöli ki annál a hatástávolságnál, ahol a kinyerni tervezett geotermikus energia mennyiségének utánpótlódása a kinyerés tervezett időtartamára biztosított mind a hőmérséklet, mind a nyomásváltozás tekintetében. Az elmúlt közel tíz évben - bár mindösszesen négy nyertes koncesszió-szerződés született (Győr, Gádoros, Jászberény és Battonya - ez utóbbi a szerződésben foglalt feltételek nem teljesülése miatt felbontásra került) a koncessziós rendszer múködőképessége és létjogosultsága igazolást nyert. A rendelkezésre álló perspektivikus területek számbavétele, valamint vállalkozói kezdeményezés alapján összesen 17 területre (4. ábra) készültek komplex érzékenységi és terhelhetôségi vizsgálati jelentések (ÉTV), amelyek mind letölthetők az MBFSZ honlapjáról, illetve az Országos Geotermikus Rendszeren keresztül (https://map.mbfsz.gov.hu/ogre).

E tanulmányok a jogszabályban meghatározott egységes tartalmi szerkezet mellett az egyes területek lehető legátfogóbb értékelését adják a terület földrajzi, földtani, vízföldtani jellemzése, földtani-geofizikai megkutatottsága, a tervezett koncessziós tevékenység hatásainak elemzése (különös tekintettel a felszíni és felszín alatti vízkészletekre és a 


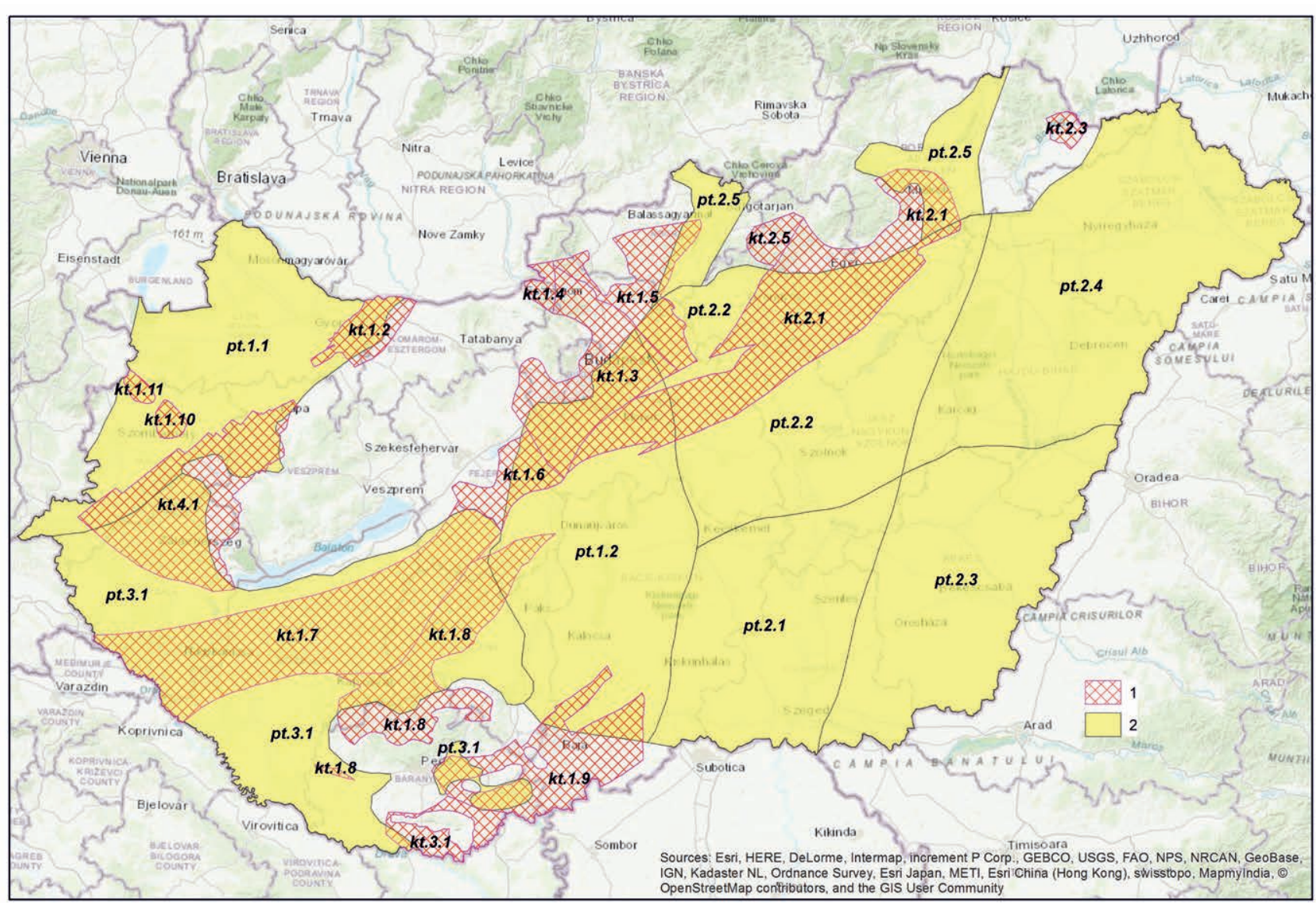

3. ábra. A porózus és karsztos termálvíztestek elterjedése (VGT-2)

Jelmagyarázat: 1 - termálkarszt víztestek, 2 - termál porózus víztestek. A számok az egyedi víztest-azonosítók (https://map.mbfsz.gov.hu/ogre)

Figure 3. Porous and karstic thermal groundwater bodies (VGT-2)

Legend: 1 - thermal karstic groundwater bodies, 2 - thermal porous groundwater bodies. Numbers are individual identifiers. (https://map.mbfsz.gov.hu/ogre)

védett természeti értékre), valamint az egyes tiltások és korlátozások (környezet-, táj-, természetvédelem, vízgazdálkodás, kulturális örökségvédelem, termőföldvédelem, településrendezés stb.) tekintetében.

Noha Magyarország geotermikus adottságai elsősorban a közvetlen hőtermelésre alkalmasak, az elmúlt évtizedekben több próbálkozás is történt az aljzati tárolók geotermikus hasznosítására áramtermelés céljából. Ezek közül a legkorábbi az iklódbördőcei projekt volt, ahol a 2006-2007ben egy magyar-ausztrál-izlandi konzorcium két meddő olajkutató fúrás termálkúttá történő átképzésével kívánt villamos energiát termelni (3-5 $\mathrm{MW}_{\mathrm{e}}$ ). Bár a villamosenergiatermeléshez feltárt termálvíz hőmérséklete megfelelő volt $\left(\sim 140{ }^{\circ} \mathrm{C}\right)$, a kutak az előzetesen becsültnél kisebb hozammal bírtak, így a projekt leállt .

A geotermikus áramtermelő projektek létesítésének a 2010-től induló koncessziós rendszer adott újabb lendületet, hiszen az áramtermelésre potenciálisan alkalmas rezervoárok zöme a 2500 m-es mélységtartományt meghaladja. A jászberényi koncessziós területen a MOL Nyrt. geotermikus leányvállalata végzett nagy volumenú földtani és geofizikai kutatásokat 2015 és 2019 között, melyek a korábbi szénhidrogén-kutatás magnetotellurikus (MT) mérésein alapultak. Megállapították, hogy a Jászberény-Ny-4 fúrás környeze- tét, valamint az attól északra levő, tektonikai elemekkel határolt részeket kifejezetten alacsony (max. 10 ohmm) ellenállás jellemzi a medencealjzat felső részén (5. ábra). Ez a kőzetek erôteljes repedezettségére, valamint a Jb-Ny-4 fúrásban feltárt, magas sótartalmú vizet tároló medencealjzati képződmények jelentős horizontális kiterjedésére utalt (BonCZ et al 2013). Azonban a felmerült nehézségek miatt (elsősorban jelentős stabil inert gáztartalom, intenzív vízkő- kiválási hajlam, valamint a magas kútszerkezeti korrózióveszély) a tervezett 3-4 MW beépített teljesítményú geotermikus erómú nem valósult meg.

Sajnálatos módon ugyancsak nem lett sikertörténet a nagy nemzetközi várakozást is kiváltó, NER-300 program által támogatott battonyai EGS (Enhanced Geothermal System - Mesterségesen javított hatékonyságú geotermikus rendszer) projekt, amely Magyarország első mesterségesen fejlesztett földhőrendszere lett volna, ahol ORC (Organic Rankine Cycle - Szerves Rankine Ciklus, alacsony forráspontú szerves segédközeg segítségével termel höenergiából áramot) technológiával, 9,8 $\mathrm{MW}_{\mathrm{e}}$ tervezett kapacitással történt volna kapcsolt hő- és áramtermelés. A kevés publikus információ hiányában tanulságként annyi fogalmazható meg, hogy a projektek elején pontosan kell definiálni, mely feltételek teljesülése szükséges a sikeres projekthez, és az ehhez 


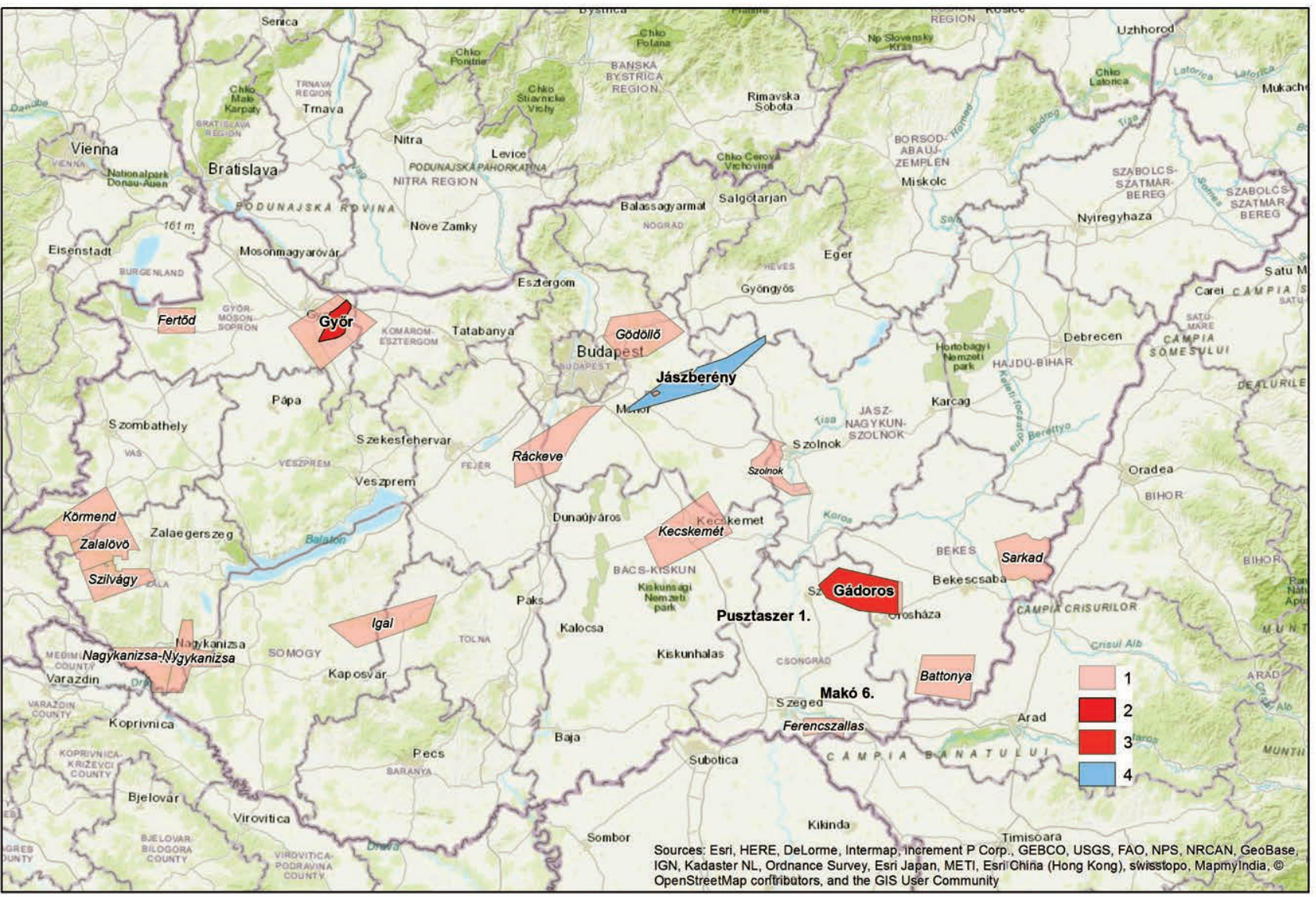

4. ábra. Érzékenységi és terhelhetőségi vizsgálati-és geotermikus koncessziós területek (2020. december 31-i állapot) (https://map.mbfsz.gov.hu/ogre) Jelmagyarázat: 1 - Komplex érzékenységi és terhelhetőségi vizsgálati jelentés, 2 -geotermikus védőidom, 3 - koncessziós terület, 4 - koncessziós kutatási zárójelentés jóváhagyása Figure 4. Areas of complex vulnerability and impact assessment studies and geothermal concessions (as of December 31, 2020) (https://map.mbfsz.gov.hu/ogre) Legend: 1-Complex vulnerability and impact assessment studies 2 - geothermal protection zone 3 - geothermal concession, 4 - approval of final exploration report (in the frame of concession)

tartozó kockázat mekkora költséggel milyen mértékben csökkenthető, különösen egy még nem piacérett technológia esetében.

A fenti sikertelenségek ellenére Magyarország 2018-ban végre felkerült a geotermikus áramtermelő országok listájára a turai erómúvel. A korábbi szénhidrogén-kutatásoknak köszönhetôen jól ismert területen a felszín alatti 1500-2200 m mélységtartományban egy kiemelt triász karbonátból álló rögból 6000 1/perc hozammal $125^{\circ} \mathrm{C}$-os termálvizet termelnek, amelyre egy 2,3 MW kapacitású ORC technológiájú erómú települt (NÁDOR et al. 2019a).

Geotermikus áramtermelésre (illetve kapcsolt hő- és áramtermelésre) irányuló kutatások jelenleg is több helyen folynak az országban, pl. Tótkomlós, Gádoros. Utóbbi térség búvópatakként már többször is felbukkant az elmúlt 30 évben az 1985-ben gőzkitörést produkáló Fábiánsebestyén-4 jelú kút kapcsán mint potenciális geotermikus áramtermelési projekthelyszín (ÁRPÁSI 1993, LORBERER et al. 2008, ÁRPÁsi 2015). A kréta, ill. középsố triász breccsásodott dolomittárolóban a kitörés helyeként feltételezett $3881 \mathrm{~m}$-be extrapolált hőmérséklet $199,6^{\circ} \mathrm{C}$, míg az extrapolált nyomás 731 bar (Вовок \& То́тн 2010b). Az extrém túlnyomás és a magas sótartalom (24-29 g/l) miatt a rezervoár hasznosítása óriási kihívás.
Az aljzati rezervoárok geotermikus hasznosításához elengedhetetlen az utánpótlási mechanizmusuk meghatározása. VAss és szerzőtársai a repedezett aljzat és a fölöttük települt porózus összletek közötti hidraulikus kapcsolatot vizsgálták fraktálgeometria alapú DFN (diszkrét töréshálózat) modellező rendszerrel (RepSim), majd modellezték a hidraulikai és hőtranszport folyamatokat (VASs et al. 2018). A számítások eredményei arra utaltak, hogy a Pannon-medence kiemelt helyzetú, túlnyomásos metamorf régiói (M. Tóтн 2008) perspektivikusak a geotermikus energia hasznosítására, mivel az alacsony permeabilitású hát peremein beszivárgó fluidumok a hát központi részén kéményszerúen feláramlanak akár $20^{\circ} \mathrm{C}$-os pozitív hőmérsékleti anomáliát létrehozva.

\section{A jelen projektek}

Magyarország csatlakozása az Európai Unióhoz 2004 ben széleskörű lehetőséget teremtett egyrészt a megújuló, köztük a geotermikusenergia-projektek finanszírozására (pl. KEOP pályázatok), másrészt a nemzetközi $\mathrm{K}+\mathrm{F}+\mathrm{I}$ együttmúködések kiteljesítésére. Utóbbi folyamat hatására sorra jöttek létre a geotermikus energia használatát megala- 


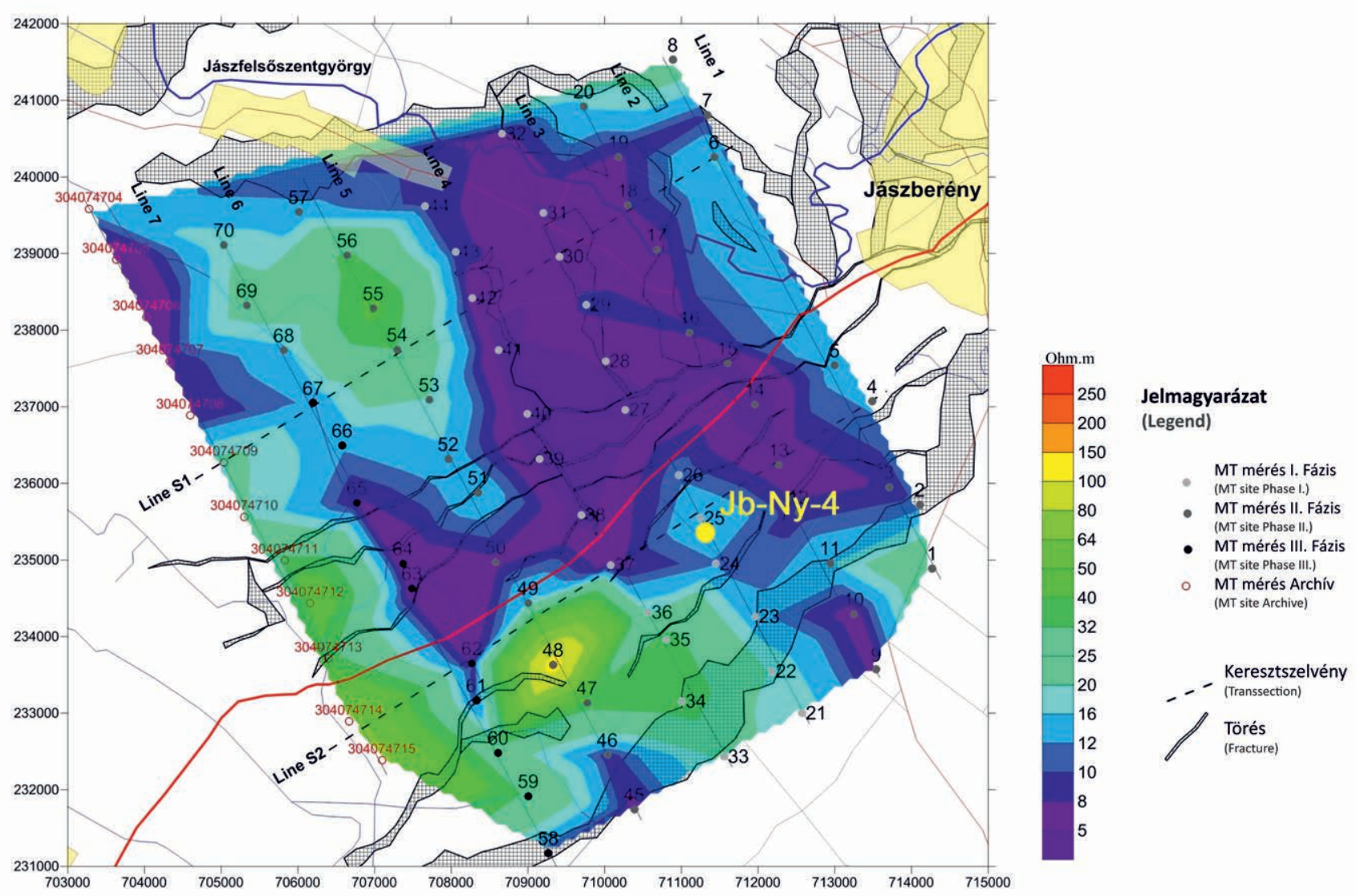

5. ábra. Ellenállás-eloszlás az aljat felszínén Jászberény térségében magnetotellurikus mérések alapján, a mérési pontok és Jászberény-Ny-4 jelü fúrás helyének feltüntetésével (eov koordinátarendszer [m]) (BoNCZ et al. 2013)

Figure 5. Resistivity distribution on the surface of the basement by Megnetotelluric survey in the vicinity of Jászberény-Ny-4 well (local coordinates [m]) (BoNCZ et al. 2013)

pozó nemzetközi projektek, melyekben magyar intézmények, civil szervezetek tagként, majd projektvezetőként vettek és vesznek részt. A nemzetközi kapcsolatok kiteljesedése a hazai szakértői csoportokat becsatornázta a világ élvonalában zajló kutatásokba, lehetôvé téve a határon átnyúló kutatási projektek indítását. Ennek nagy jelentősége van, mert a jelenlegi termálvíztermelés, nem beszélve a kívánt növekedésről, regionális hidrodinamikai hatást vált ki. Az utánpótlódási területek egy jelentős része a Kárpát-medencét övezô peremi hegyvidékeken helyezkedik el, ahol a beszivárgó csapadékvíz a mélybe jutva felmelegszik, és a hidrosztatikai nyomásviszonyoknak megfelelően a medence arra földtanilag-vízföldtanilag alkalmas egységeiben áramlik a természetes vagy mesterséges megcsapolási pontok felé (6. ábra). A meglevő tapasztalatok igazolják, hogy különösen a határ menti régiókban egy adott ország fokozott termálvíztermelésének esetleges negatív hatásai (depresszió, hozam- és hőmérséklet-csökkenés stb.) a szomszédos országokban is jelentkezhetnek (TóтH et al. 2010) (7. ábra), ezért regionális szinten csak egy határokon átnyúló, a szomszédos országokkal közösen kialakított gazdálkodási stratégia vezethet a termálvizek fenntartható használatához.

A határokon átnyúló vizsgálatok fontosságára, az országos földtani-vízföldtani adatbázisokra, a regionális léptékú geológiai-hidrogeológiai modellezések korábbi eredményei- re, illetve a szomszédos országok földtani intézményeivel kialakított szoros együttmúködésre támaszkodva a Magyar Bányászati és Földtani Szolgálat (MBFSZ), illetve jogelőd intézményei az elmúlt évtizedben több nemzetközi projektet koordináltak (T-JAM, Transenergy, DARLINGe), melyek célja a határokon átívelő geotermikus erőforrások felmérése és értékelése volt. Ezekben elsősorban Magyarország ÉNyi, Ny-i, illetve DNy-i, D-i és DK-i határvidékein a szomszédos országokkal közösen létrehozott földtani, hidrogeológiai és geotermikus modellekre alapozva regionális léptékben lehatárolták a potenciális geotermikus rezervoárokat (RoTÁR-SZALKAI et al. 2017, NÁDOR et al. 2019b) vizsgálták a geotermikus energia hasznosításának lehetôségeit (RMAN et al 2015, 2020), a fenntartható termálvíztermelés peremfeltételeit (NÁDOR et al. 2012, TóTH et al. 2016, SzŐ́cs et al. 2018), az esetlegesen tervezett új geotermikus rendszerek egymásra hatásait, valamint a hatékonyabb termálvíz-hasznosítás lehetőségeit (NÁDOR 2019).

A fenti projektekben egy többlépcsôs módszeregyüttes került kidolgozásra, amely az évek során egyre finomodott, és újabb részletekkel egészült ki. Első lépésben az adott projekt területén részletes felmérés készült a múködő termálvízhasznosításokról, a kutak adatairól (pl. kifolyó víz hőmérséklete, hozama, a szúrőzött szakaszok mélysége, a vízadó litológiája, a felhasználás módja stb.), amelyekből nyilvá- 


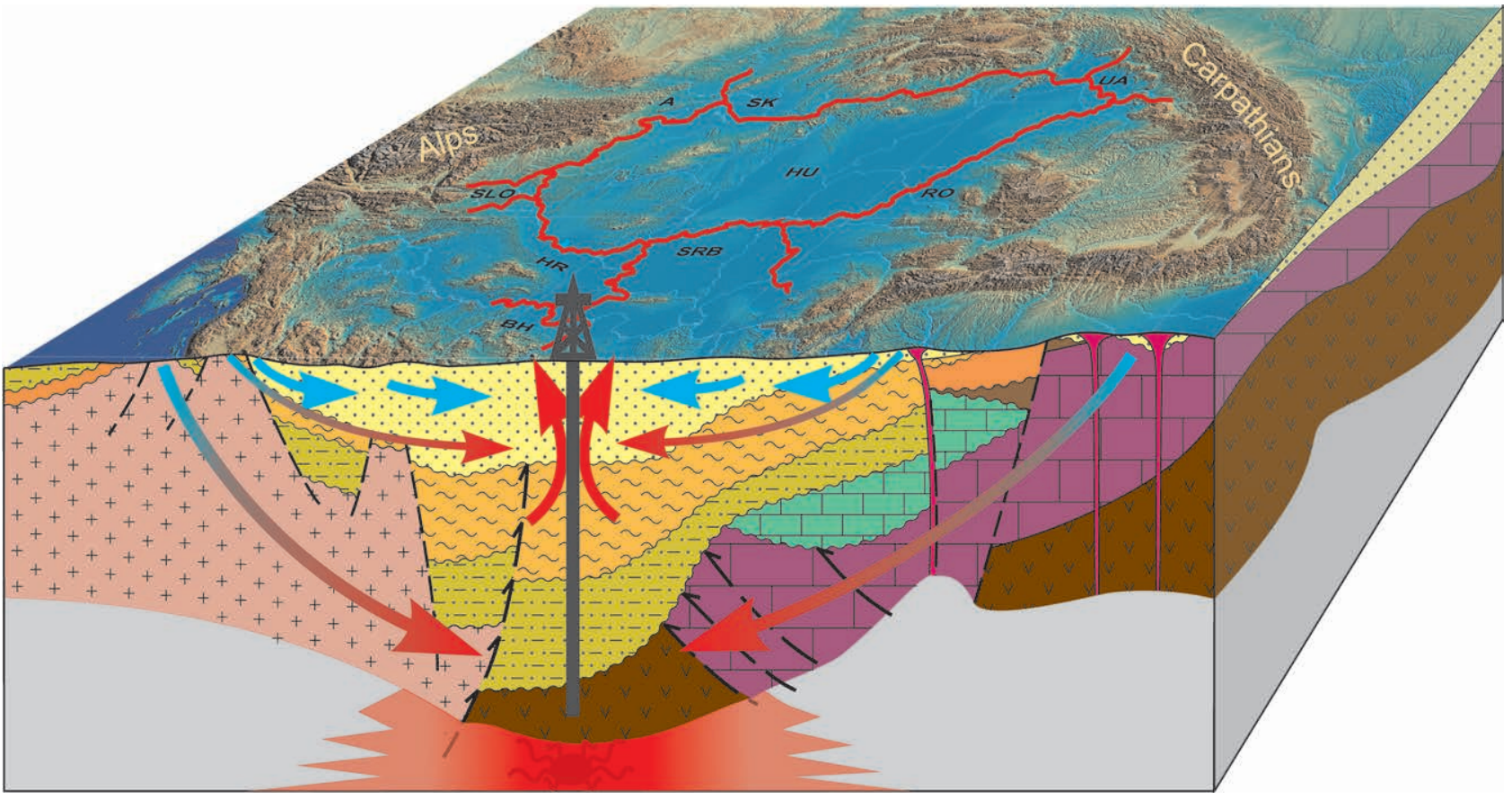

6. ábra. A Kárpát-medence regionális határokon átnyúló termálvíz áramlásainak elvi vázlata (NÁDOR ed. 2019)

Figure 6. Schematic sketch of the regional cross-border thermal groundwater flow of the Carpathian basin (NÁDOR ed. 2019)

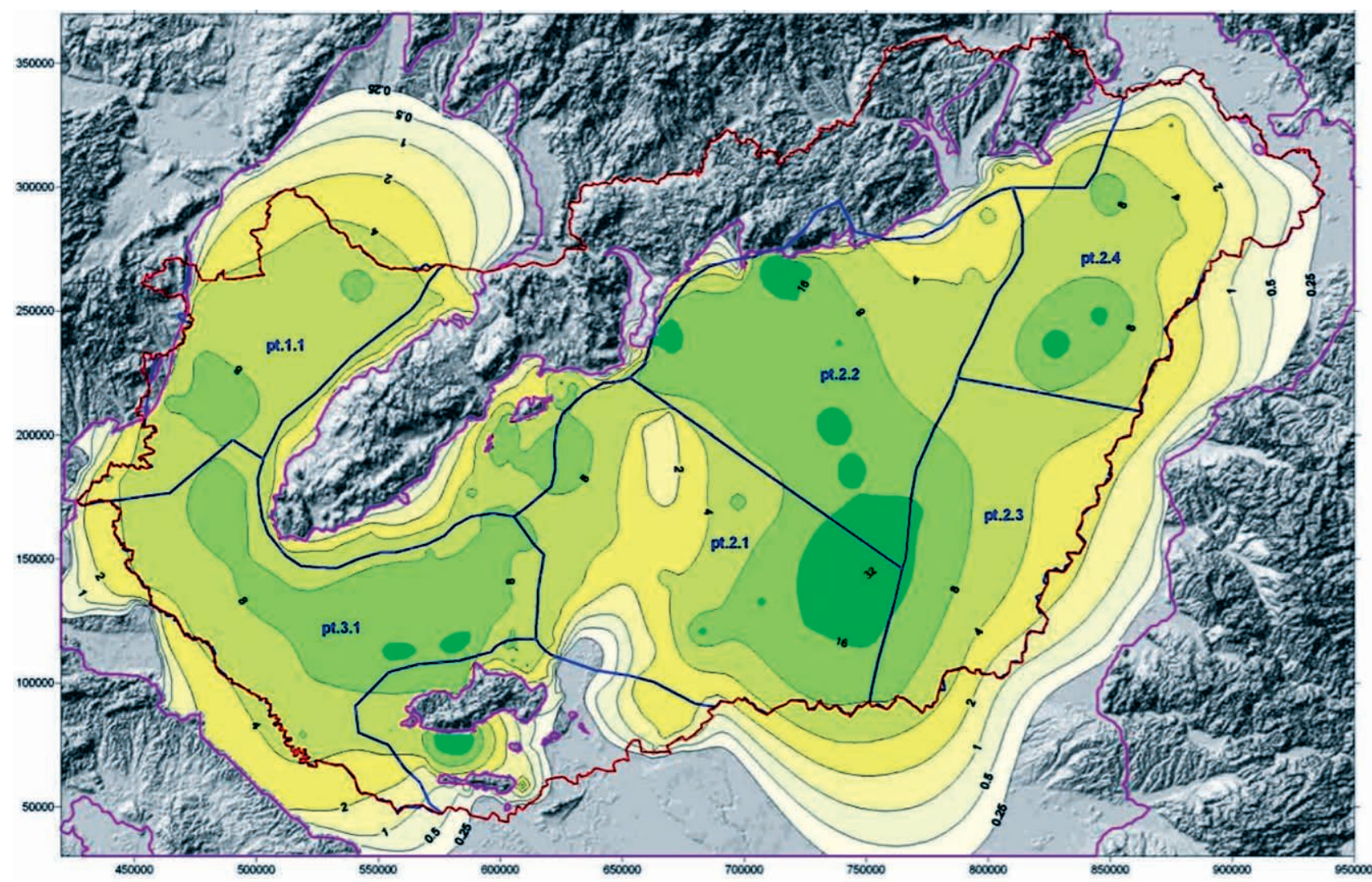

7. ábra. A hideg-és hévíztermelések együttes hatására létrejövő depresszió (m) a pannóniai sekélyvízi, deltaeredetủ homokkö-rezervoár alján a 2000-es évek elejének kvázi permanens állapotára számítva (TóTH et al. 2010)

Figure 7. Depression $(\mathrm{m})$ at the bottom of the Pannonian shallow sandstone reservoir due to the cummulated cold and thermal water abstraction calculated for the quasisteady state conditions of the beginning of the 21st century (TótH et al. 2010) 
nos, a projektek honlapjain elérhető adatbázisok épültek, és amelyek az adatok sok szempontú lekérdezhetőségét és megjelenítését is lehetôvé tették (8. ábra). A T-JAM-projektben 13 szlovén és 43 magyar termálkút főbb felhasználási adatai kerültek összegyújtésre (JuHÁsz et al. 2013). A négy országot lefedő Transenergy-projekt hasznosítási adatbázisa összesen 403 termálkút (AT: 48, HU: 259, SK: 59, SI: 37) adatait közli (RMAN et al. 2015), míg a Pannon-medence Di határát vizsgáló DARLINGe projekt már hat ország 771 geotermikus objektumának (BH: 10 kút, HR: 6 forrás és 25 kút, HU: 606 kút, RO: 55 kút, SRB: 1 forrás, 24 kút, SI: 44 kút) részletes adatait elemezte (RMAN et al. 2020).

Ezt követően a vizsgálandó területre meghatározásra kerültek a fóbb hidrosztratigráfiai egységek ( $a$ vízföldtani szempontból hasonlóan viselkedö kózetegyüttesek), és olyan földtani térmodellek készültek, amelyek alapján ezen egységek határoló felületei megadhatók. Ezek a mélyföldtani szintek általában a prekainozóos aljzatfelszínt, a pannóniai korú mélyvízi képződmények talpát, a sekélyvízi delta üledékek talpát és a kvarter talpat jelentették, és az adott projektterület nagyságától függően 1:100 000 - 1:500 000 léptékben lettek megszerkesztve (MAROs et al. 2012). A földtani modell képezte a numerikus vízföldtani modellek vázát, amelyek segítségével megadhatók voltak a főbb nyo- másszintek és az országhatárokon átívelő regionális áramlási pályák, valamint számszerúsíthetővé váltak az egyes vízföldtani egységek közötti vízmérlegadatok. A különböző földtani és geotermikus modellfelületek kombinációjával lehetőség nyílt a geotermikus rezervoárok főbb típusainak lehatárolására és térbeli megjelenítésére is (RoTÁR-SzALKAI et al. 2017, NÁdOR et al. 2019b) (9. ábra).

Különböző szcenáriók futtatásával ezen modellek segítségével előre jelezhetôk a különböző termelések jövőbeli regionális hatásai is, amelynek fontos szerepe lehet a vízgazdálkodási kérdések eldöntésében. Így például a Transenergy-projektben a modellezés kimutatta, hogy a természetes (termelés előtti) állapotban a termálvíz áramlási iránya a térségben Magyarországról Ausztria, illetve Szlovéniából és Szlovákiából Magyarország felé irányult. Ugyanakkor a jelenlegi víztermelések hatására az országhatárokon átadott vízmennyiségek valamennyi esetben jelentősen lecsökkentek, a vízszintcsökkenés mértéke a határ menti részeken 2-10 m nagyságrendú, a depressziók mélyen benyúlnak a szomszédos országokba, illetve a vízáramlás iránya is megváltozott Magyarországról Szlovákia irányába. Amennyiben egy jövőbeli ötszörös megnövelt termálvízkivétellel számolunk, akkor az országhatárok mentén jelentkező depressziók akár a 30 m-t is meghalad-

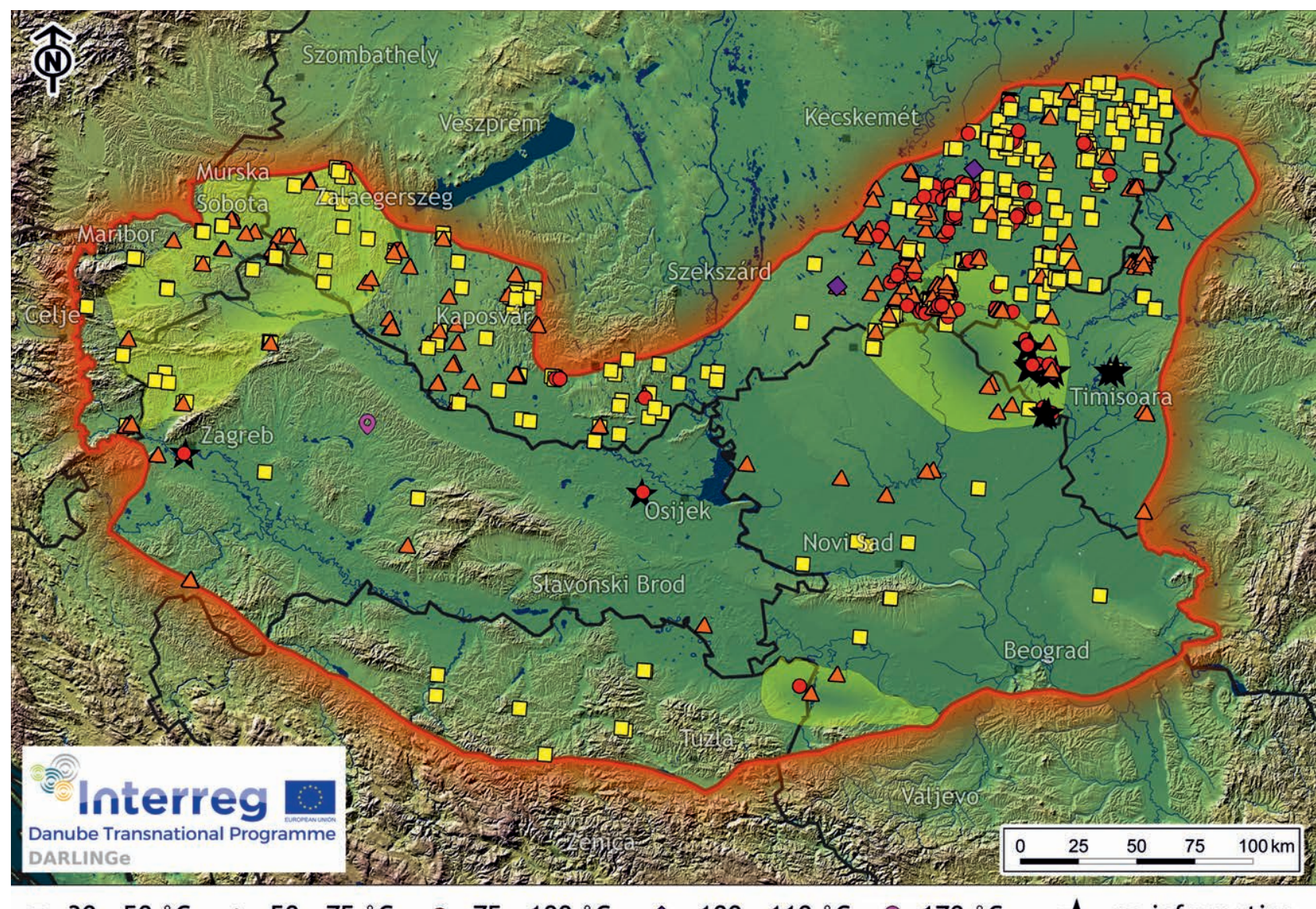

$30-50{ }^{\circ} \mathrm{C} \triangle 50-75^{\circ} \mathrm{C} \quad 75-100{ }^{\circ} \mathrm{C}$

$100-110^{\circ} \mathrm{C} \odot 170{ }^{\circ} \mathrm{C}$

no information

8. ábra. A geotermikus objektumok (források és kutak) kifolyó víz hőmérséklet szerinti megoszlása a DARLINGe-projekt területén (RMAN et al. 2020) Figure 8. Distribution of outflow temperature of geothermal objects (springs and wells) on the DARLINGe project area (RMAN et al. 2020) 

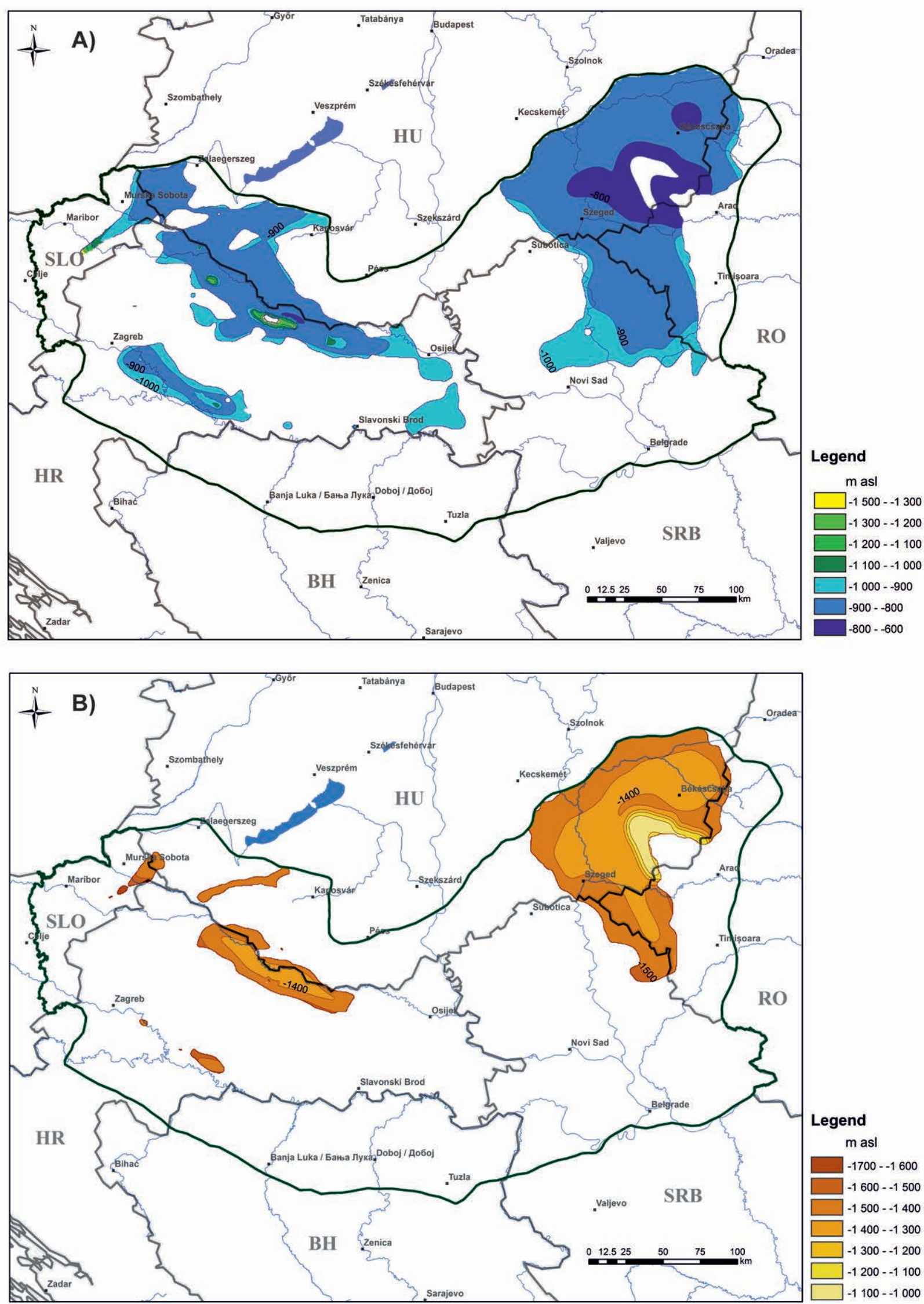

9. ábra. A porózus $50-75^{\circ} \mathrm{C}(\mathrm{A})$ és $75-100{ }^{\circ} \mathrm{C}(\mathrm{B})$ rezervoárok tetőszintje a DARLINGe projekt területén (RoTÁR -SzALKAI et al. 2018)

Figure 9. Top bounding surface of the porous geothermal reservoirs storing thermal water $50-75^{\circ} \mathrm{C}(A)$ and $75-100^{\circ} \mathrm{C}(B)$ on the DARLINGe project area (RoTÁR-SZALKAI et al. 2018) 
hatják, maguk után vonva az áramlási rendszer további regionális változását (TóTH et al. 2016).

A geotermikus potenciál értékelése érdekében a földtani és vízföldtani modellek természetesen kiegészültek geotermikus modellekkel is (LENKEY et al. 2008, LENKEY et al. 2021). Ezek általában a felszín alatti hőmérséklet-eloszlásokat mutatják izotermatérképek (adott hőmérséklet mélybeli eloszlása), vagy mélység-hőmérséklet (adott mélységben érvényes hőmérséklet-eloszlás) térképek formájában. A legújabb feldolgozások eredményeiról bővebb információ található a Földtani Közlöny jelen számában (LENKEY et al. 2021).

Mindezen közös földtani, vízföldtani és geotermikus modellek kialakítása csak a szomszédos országok közötti harmonizált adatok alapján volt lehetséges, ezért a modellépítéseket minden esetben hosszú adatgyújtési és adatharmonizációs fázis előzte meg. Sok esetben komoly problémát jelentett a rendkívül heterogén adatsưrúség, az adatok eltérô minősége és megbízhatósága, valamint a korlátozott adathozzáférések. Ennek ellenére a projektekben kialakított közös adatbázisokat, az integrált értelmezések eredményeit bemutató webes térképi megoldások (http://transenergyeu.geologie.ac.at/, (https://www.darlinge.eu/mapviewer/ index.html) az egyik legnagyobb értékei az együttmúködéseknek, amelyekre további kutatások is alapulhatnak.

2012-2015 között a Miskolci Egyetem Környezetgazdálkodási Intézete a KÚTFŐ (TÁMOP-4.2.2.A) projekt keretében egyebek mellett a Tokaji-hegység geotermikus adottságainak felmérését végezte. A területen található közel 700 kút és számos forrás adatait, valamint a korábbi kutatások eredményeit felhasználva összeállították a Tokaji-hegység hidrogeológiai és vízkémiai adatbázisát. A Kéked-Szerencs törésvonal terepi mintavételezése során egy korábban le nem írt hévizes anomáliát tártak fel Korlát térségében, melyet multielektródás geofizikai vizsgálatokkal igazoltak. A kutatócsoport elkészítette a terület kalibrált regionális hidrodinamikai modelljét. A vizsgálatok eredményeként új termálkutak helykijelölése is megtörtént. (Szứcs et al. 2014).

A közelmúltban zajlott kutatási projektek közül említést érdemel még az Európai Bizottság Horizon 2020 programja által finanszírozott, a Miskolci Egyetem Földtudományi Kara vezetésével és a Szegedi Tudományegyetem Ásványtani, Geokémiai és Kőzettani Tanszéke közremúködésével megvalósított CHPM2030 (Combined Heat, Power and Metal Extraction - Kombinált hö-, elektromos áram-, fémkinyerés) kutatás-fejlesztési projekt (https://www.chpm2030.eu), mely a geotermia, a fémkinyerés, hidrometallurgia határterületein kutatva újraértelmezi azt az ősrégi tudást, mely szerint a geotermikus erőforrások nem ritkán értékes ásványinyersanyag-dúsulásokhhoz kapcsolódnak. A technológiafejlesztési projekt a nagy mélységú, hagyományos bányászati eljárásokkal nem múvelhető ércdúsulásokat kívánja speciális EGS- rendszerré fejleszteni (orebody-EGS). Az elképzelés lényege, hogy a geotermikus adottságainál fogva villamosenergia-termelésre alkalmas létesítmény gazdaságossági mutatói jelentősen növelhetők, ha a villamosenergiatermelés és a hőkinyerés mellett pl. kritikus ásványi nyersanyagok, ritka földfémek felszínre hozatalával és felszíni leválasztásával javítjuk a beruházási költségek gyorsabb megtérülését (MADARÁSz et al. 2019) (10. ábra). A projekt-koncepció az alkalmazható kioldási és réteg-stimulációs mód-

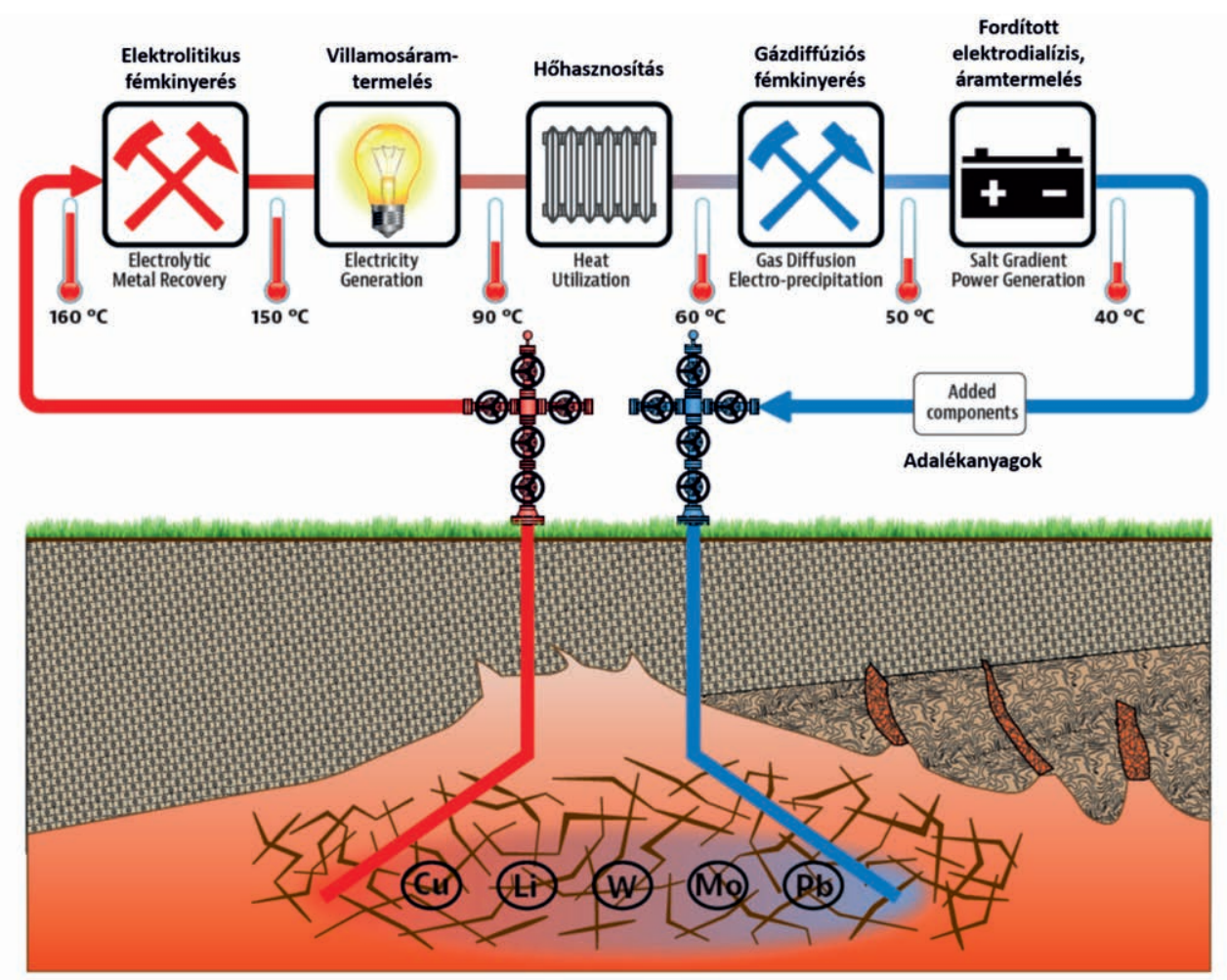

10. ábra. A CHPM-koncepció sematikus ábrája (MADARÁsZ et al. 2019)

Figure 10. Schematic figure of the CHPM concept (MADARÁSZ et al. 2019) 
szerek vizsgálata mellett két fémleválasztási technológia fejlesztését tűzte ki célul, azokat célzottan geotermikus kútpárok felszíni létesítményeiként alkalmazva. A feladat keretében a konzorcium 12 tagja közül, az említett magyarok mellett a Brit Geológiai Szolgálat (BGS), a VITO és a Leuveni Katolikus Egyetem (mindkettő Belgium), valamint az ISOR (Izland) képviselői az európai földtani, geotermikus adatok összegyújjtésén, rendszerezésén túl egy intenzív, szisztematikus laboratóriumi kísérleti programot hajtottak végre (OsVALD et al. 2018). A múszaki fejlesztések mellett a projekt foglalkozott a technológiai fejlesztés környezeti és gazdasági hatásainak/feltételeinek vizsgálatával is. A fémkinyerési technológia kifejlesztése és a fordított elektrodialízis elvú, másodlagos áramfejlesztési módszer felskálázását követően a projekt aktív, finanszírozott szakasza lezárult (MADARÁSZ et al. 2019). A konzorcium a pilot üzemet eredetileg 2030-ra prognosztizálta. Azonban a felvázolt technológiai kör egyes elemei önmagukban is alkalmazhatók már üzemelő geotermikus rendszerek esetén fémkinyerésre. Ugyanakkor meg kell jegyezni, hogy a laboratóriumi kísérletek félüzemi, majd ipari szintre történő „,felskálázása” és az egyes technológiai elemek összekapcsolhatóságának szabályozása ko- moly mérnöki és modellezési kihívások elé állítja a jövőben a kutatókat.

Egy másik örökzöld probléma a meddő és használaton kívüli kutak energetikai hasznosíthatósága. A Miskolci Egyetem kutatói által vezetett projekt (GINOP-2.3.2-15-201600010) elvégezte a vizsgált meddő szénhidrogénkutak területléptékű energetikai értékelését, illetve kitért az erőmúvi/ ipari hulladékhő vagy megújulókból származó energia földtani közegben történő tárolásának hatékonyság/hatásfok vizsgálatára a Bükk-alja, Borsodi-mezőség és a Hevesi-sík mintaterületeken.

A hazánkban jelenleg folyó legnagyobb geotermikus projekt megvalósítását a Szegedi Távfútő Kft., a Geo Hőterm Kft. és a Nemzeti Fejlesztési Programiroda Kft. alkotta konzorcium végzi KEHOP pályázati támogatással. A 2018ban kezdődött és várhatóban 2023-ban befejeződő fejlesztés során 9 távfűtőrendszert állítanak át geotermikus üzemre. A projektben 9 termelő és 18 visszasajtoló kút mélyül az 1700-2000 m között szúrőzött pannóniai korú sekélyvízi homokrétegekbe, melyek átlagosan $80 \mathrm{~m}^{3} / \mathrm{h}$ hozammal $90^{\circ} \mathrm{C}$ hômérsékletű termálvizet termelnek (11. ábra). A 27 ezer lakás mellett 500 középület fütési energiáját és használati

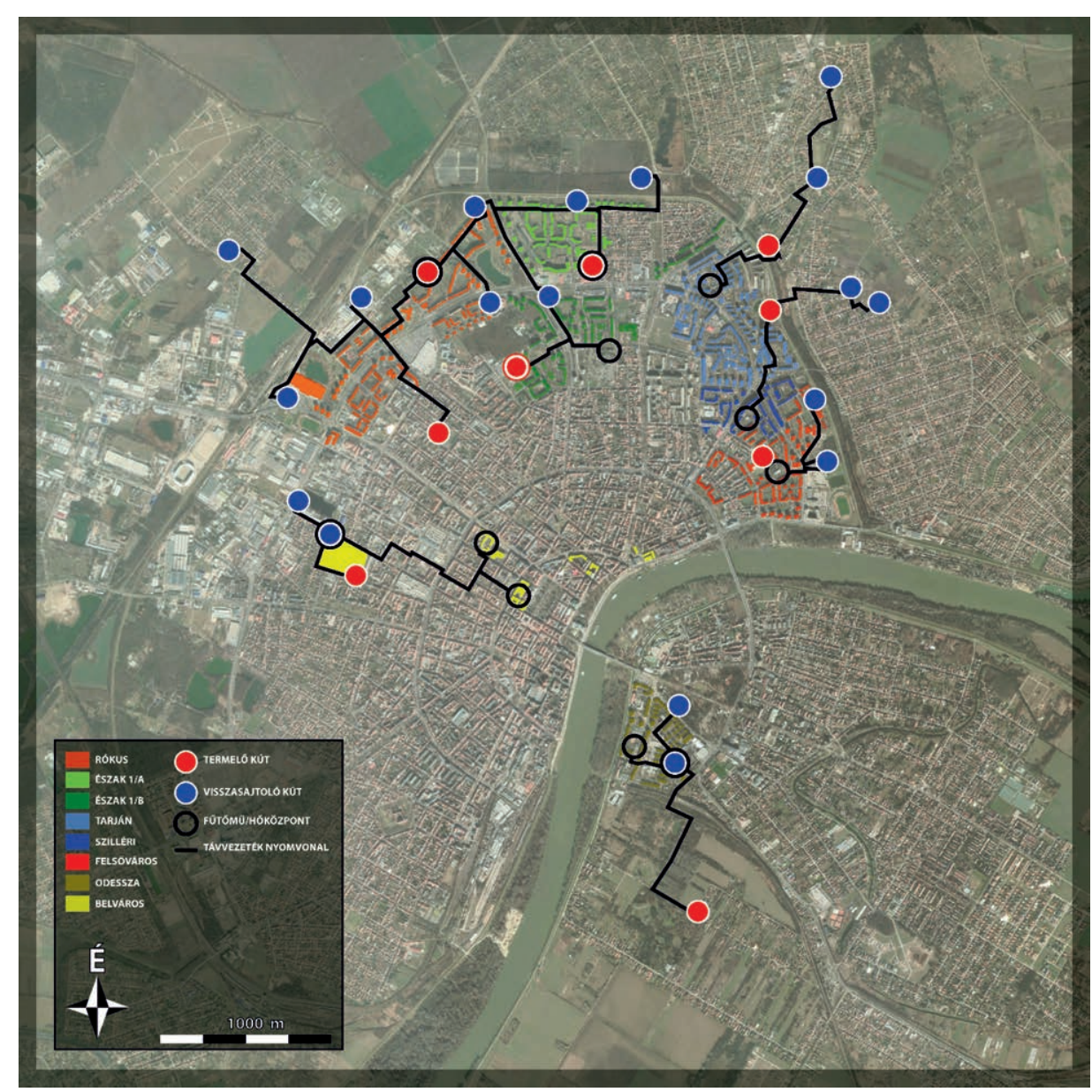

11. ábra. Épülő Szegedi Geotermikus Távhőrendszer vázlatrajza a tervezett kutak és hőközpontok helyének feltüntetésével (SZETÁV 2019)

Figure 11. Schematic map of the Szeged Geothermal District Heating System under construction with the location of the planned wells and heating centers (SZETÁV 2019) 
meleg vizét biztosító, 224MW th névleges kapacitású távfütő- rendszer a város jelenlegi legnagyobb levegőszenynyezője, így a geotermikus energia használatához a gazdasági hasznon túl jelentős környezeti előnyök is társulnak. A projekt eredményeként évente közel 15 millió m³ földgáz váltható ki 350 ezer GJ geotermikus energiaforrással, évi 25 ezer tonna $\mathrm{CO}_{2}$-al mérsékelve Szeged város levegőjének üvegházhatású gázterhelését. A fejlesztés hatására az érintett fütési körök esetében kb. 70\%-os, a teljes szegedi távfütés tekintetében pedig 50\%-os lesz a helyben lévő megújuló energia részaránya, így a levegố állapotán túl az ellátás biztonsága is javul (OsvaLD et al. 2017).

\section{A futó kutatások, jövókép}

A kiemelkedő geotermikus adottságaink és az előzőekben bemutatott jelentős kutatási előzmények mellett is megállapítható, hogy a földhőhasznosítás máig nem tudott átütő szerephez jutni a megújuló energiahordozók versenyében Magyarországon. Hazánkban az energiaforrások közel 40\%át fütésre használjuk (387 PJ/év) és ebből geotermikus energia csak 6 PJ/év (KuRUNCZI 2017). A rendelkezésre álló geotermikus erőforrások jobb kihasználására számos tanulmány született, országosan (MÁdL et al. 2008), megyei bontásban (TóTH 2016) vagy konkrét 40 éves cselekvési tervet felvázolva (MTA et al. 2015). Közös megállapításuk, hogy a jelenlegi hasznosításnál legalább egy nagyságrenddel nagyobb geotermikus energia is hasznosítható lenne gazdaságosan, fenntartható módon. A financiális és jogszabályi akadályokon túl a hasznosítható potenciált technológiai, gazdaságossági, környezeti (fenntarthatósági) és nem ritkán társadalmi szempontok is korlátozzák. Továbblépést - a kedvező politikai és gazdasági szabályozói környezet megteremtésén túl - a szakterületben rejlő, kiaknázatlan $\mathrm{K}+\mathrm{F}+\mathrm{I}$ lehetôségek jelenthetnek.

A jelenleg folyó hazai kutatások jelentős részben elméleti és gyakorlati jellegú technológiai fejlesztésekre, kisebb mértékben geotermikus területek kutatására irányulnak, mint például az Eötvös Loránd Tudományegyetemen MÁDLNÉ SZŐNYI Judit és munkatársai által folytatott budai termálkarszt kutatása. Összefoglaló munkájukban a fluidum fejlődéstörténetét az ásványparagenezisek tükrében vizsgálták a késő miocén fedett karbonátos állapottól, mikor még a termikus felhajtóerő vezérelte a felszín alatti vízáramlást. Eredményeik rámutatnak a jelenlegi vízáramlás aszimmetrikus jellegének okaira, a rendszer hőmérsékleti eloszlását meghatározó folyamatokra, valamint a fedőüledékek hőfelhalmozódásban betöltött szerepére (MÁDL et al. 2018).

Hasonlóan nagy volumenú a Geotermikus Budapest vízióját felvázoló tanulmány (MEKH 2020), mely komplex módon a hőszivattyús hasznosítástól a geotermikus áramtermelésig vizsgálja a főváros geotermikus energiával történő ellátását. A nagy entalpiájú hasznosításoktól eltekintve számos kiaknázatlan lehetőségre hívja fel a figyelmet a geotermikus hőszolgáltatásban. A szerzók megállapítása szerint különösen Kelenföld, Kispest és Újpest gázalapú távfú- tő központjainál 30-50\%-ban, míg Rákospalota esetében teljes mértékben kiválthatná a gázfelhasználást a termálvízalapú fütés.

A geotermikus szektor számára egyik legérzékenyebb és ezért régóta kutatott terület a porózus tárolókba való visszasajtolás. Alapvető megállapítás, hogy az adott porózus rezervoár nyelőképessége párhuzamosítható vízadóképességével, ha kútkiképzés, felszíni szúrés és üzemeltetés hármasánál meghatározott szempontok teljesülnek (SZANYI et al. 2013). Azonban a pontos feltételrendszer meghatározásához elengedhetetlen a képződmények kőzetmechanikai, kőzetfizikai és kőzetszöveti paramétereinek, valamint a közöttük lévő összefüggéseknek az ismerete (HoRvÁTH et al. 2013). Ehhez kapcsolódóan a Miskolci Egyetem kutatói a fúróiszap-kiszúrődés hatását vizsgálták valós magmintákon egy újonnan kifejlesztett kísérleti eszköz segítségével (VARGA et al. 2020). Új módszerükkel a permeabilitás változás mértékének meghatározása mellett a kiszúrődés mértékének időbeli változása is leírható.

Átfogóan, laboratóriumi és terepi kutatásokkal alátámasztva tervezi a visszasajtolás technológiáját fejleszteni a „Fenntartható és költséghatékony termálvíz visszasajtolás kút kiképzési technológiájának kifejlesztése" (GINOP2.2.1-15-2017-00102) címú K+F projekt, melynek célja gazdaságos, a jelenlegi hazai gyakorlatban alkalmazottnál hatékonyabb technológiák kifejlesztése és pilot projektként történő demonstrációja egy meglévő kút átalakításával, illetve egy új technológiájú kút fúrásával. Mindezzel lehetôvé kívánják tenni a fenntartható geotermikus energiatermelés megvalósítását a nagy geotermikus potenciállal rendelkező, pannóniai sekélyvízi homokkövekből.

A termálvíz-hasznosítás velejárója a vízben oldott ásványok kicsapódása, ami a különbözô szerelvények (szivatytyúk, csövek, szelepek, hőcserélők) fokozatos eltömődése miatt a geotermikus hő- és villamosenergia-termelésben komoly gondokat okozhat. A Pannon-medence változatos fluidumai jó lehetőséget teremtenek a vízkőkiváláshoz vezető folyamatok megértéséhez. BocH et al. (2016) megállapították, hogy a csôvezetékek korrodált rétege meghatározó szerepet játszik az ásványcsírák képződésénél.

A vízkőkiválás okait a tároló képződmény oldaláról vizsgálták a Szegedi Tudományegyetem munkatársai, a Szeged térségében futó geotermikus projekt furadékanyagait és vízkőkiválásait elemezve (VARGA et al. 2019). Ehhez a pannóniai sekélyvízi homokkótároló és a dominánsan Na$\mathrm{HCO}_{3}$ típusú termálvizek egymásra hatását vizsgálták integrált ásványtani, kőzettani és vízkémiai módszerekkel. Fő megállapításuk, hogy az intenzív vízkókiválásnak a nem hagyományos sziliciklasztos homokkőtároló ásvány-kőzettani összetétele lehet lehet az oka, a szemcsék között ásványtanilag éretlen dolomit és mészkő fragmentumok találhatók, melyek aránya elérheti a 20-25\%-ot.

Geotermikus energiát fluidumtermelés nélkül is lehet hasznosítani, különösen kis hőigény esetén. Fontos megemlíteni, hogy a sekély mélységú (Magyarországon általában 100 m) földhő szivattyús rendszerek világszerte a geotermikus technológia legsikeresebb piaci termékei, jelenleg a 
globális beépített kapacitás 77,547 MW , az energiafelhasználás pedig közel 600 PJ/év (LunD \& TóTH 2020). A geotermikus hőszivattyús technológia magyarországi alkalmazása messze a lehetôségek mögött kullog annak ellenére, hogy KoMLós Ferenc évtizedekig érvelt a hasznosítás kiszélesítése mellett (KomLós et al. 2009). Bár a hőszivattyús rendszerek telejesítménye általában $\mathrm{kW}_{\mathrm{th}}$ nagyságrendú (ÁDÁm et al. 2019), léteznek nagy teljesítményú földhőszondás hőszivattyús rendszerek, mint a pápai katonai repülőtéren, ahol NATO-beruházás keretében az ország legnagyobb sekély geotermikus rendszere készült el $270 \mathrm{db} 100 \mathrm{~m}$-es szondával, melynek fútési teljesítménye 1,65 $\mathrm{MW}_{\mathrm{th}}$, míg hútési teljesítménye $0,72 \mathrm{MW}_{\text {th }}$ (https://hgd.hu/hu/referenciak/ magyarorszag-legnagyobb-hoszivattyus-foldhoszondasrendszere-papa-bazisrepuloter-nato). Ugyanakkor nagyobb mélységbőll, akár több ezer méteres mélységből is lehetséges zárt rendszerben hốt kinyerni. Ha egy béléscsövezett mélyfúrású kutat alul, perforálás nélkül lezárunk, akkor a koaxiálisan beépített termelőcsô és a béléscső közötti gyứrús térben áramlik lefelé a felmelegítendô víz. Mivel a kút környezete a mélység mentén egyre melegebb, az áramló víz útja során fokozatosan felmelegszik, miközben a kutat körülvevő kőzeteket lehúti, majd a termelőcsövön feláramlik. Egy ilyen módon kiképzett 2000 m mély geotermikus energiát termelő, zárt rendszerú kút hőmérséklet-viszonyainak számítására dolgozott ki analitikus, szemianalitikus megoldást Вовок \& То́тн (2007). Számításuk szerint a pannóniai korú rétegekre mélyített, koaxiális kiképzésú kút csak hôszigetelt termelốcsővel és hôszivattyúval kiegészítve múködtethetố gazdaságosan. Fenti metodika eredményeit felhasználva KALMÁR és munkatársai (2020) kalibrált numerikus módszert fejlesztettek ki a nagy mélységú hőcserélők (Deep Borehole Heat Exchanger) múszaki és pénzügyi megvalósíthatóságának tanulmányozására vákuumszigetelt termelő́csövek használata esetén. A kalibrált numerikus módszerrel lehetôvé vált a természetes konvektív tömegáram szimulációja $40^{\circ} \mathrm{C} / \mathrm{km}$-tól $60^{\circ} \mathrm{C} / \mathrm{km}$-ig terjedő geotermikus gradiensek között. A tanulmány alapján a felvázolt nagy mélységú hôcserélő rendszer megvalósítása gazdaságilag nyereséges projektet eredményezhet, ha a befogadó távhőrendszer elég nagy a folyamatos üzemhez, azaz az éves teljes értékesített hőmennyiség eléri a 25000 GJ-t.

A geotermikus $\mathrm{K}+\mathrm{F}$ tevékenység egy új iránya a más iparágakban már bizonyított, nagy teljesítményú lézerek kútkiképzésre, kútjavításra, karbantartásra történő használata. A lézeres fúrási egység egy speciális felszíni, nagy teljesítményư lézergenerátorból és egy kútban lévő lézerfejből áll, melyeket páncélozott optikai szál köt össze. A lézernyaláb nitrogénbuborékban végzi a munkáját, ez nyomja el a kútban lévő fluidumot a fej elől, és söpri ki a képződő olvadékot (BAJCSI et al. 2015). A nagy teljesítményú lézeregység (6-24kW), kialakításától függően, alkalmas vágásra, perforációképzésre, kis átmérőjú laterális fúrások készítésére és a kútban lévő ásványkiválások eltávolítására. Az új, lézeres kútmunkálati technológia alacsony karbantartást igényel, nem tartalmaz semmilyen mechanikus alkatrészt vagy bármilyen vegyi anyagot, miközben in situ, valós idejú vissza- csatolást kínál az optikai szálon keresztül (videójel és spektroszkópia) az eszköz kezelőjének (http://www.zerluxhungary. com/laser-pipe-cutter). KovÁCs és munkatársai (2014) pannóniai korú homokkő magmintákon vizsgálta a lézeres fúrás környezetének áteresztóképesség-változását. Megállapították, hogy a lézerrel kezelt furat falán képződő kôzetüveghab és a félig olvadt szemcsék egy mesterséges szúrőrendszert hoznak létre (szintereződés), mely a folyadékok és gázok számára átjárható, míg a szilárd részecskékkel szemben szûrőhatású, ezzel megakadályozva a homokolódást. Továbbá mérésekkel igazolták, hogy a lyukfal áteresztóképessége növekedett a hôhatás okozta repedések miatt. Az új technológia alkalmazása elősegítheti a visszasajtoló kutak nyelőképességének növelését. A vizsgálatok járulékos eredménye, hogy a lézer okozta hősokk a kőzetekben mikrorepedéseket generál, így a technológia alkalmas lehet mechanikai rétegstimulációra például EGS-rendszerek esetén. A CHPM2030-projekt keretében a lézerrel kezelt kőzeteken végrehajtott kőzetmechanikai vizsgálatok a feltételezést alátámasztották (SZANYI et al. 2017).

Általános vélekedés a nemzetközi geotermikus fórumokon, hogy a geotermikus energiahasznosítás jövőbeli sikerét az EGS-technológia tökéletesítése jelentheti (TESTER et al. 2006, RYBACH 2010). A nagy mélységú, magas hômérsékletú EGS-rendszerek elterjedését azonban még számos kihívás nehezíti. A technológiával szemben fel-fel lángoló gyakran megalapozatlan - társadalmi ellenállást leszámítva is komoly gazdasági, befektetői kockázatot jelent az EGSrendszerek telepítése és üzemeltetése. A rendkívül magas kezdeti beruházási költségek és a földtani, múszaki kockázatok jelentősen visszafogják a beruházási kedvet, még akkor is, ha a sikeres beruházás esetén a megtérülés garantálható.

Az European Technology Platform for Deep Geothermal (ETIP-DG) szakmai szervezet meghatározó szerepet tulajdonít a kutatás-fejlesztésnek, és a jövő szempontjából kulcsfontosságú eredményeket vár az innovációs projektektől. A 2018-ban publikált kutatás-fejlesztési jövőképben (ETIP-DG 2019) releváns fókuszterületként az alábbi témákat jelöli ki:

1. A nagy mélységú, komplex földtani rendszerek jobb megismerése nagy felbontású és költséghatékony feltárási módszerek/eszközök segítségével.

2. A hőkihozatal növelése a fúrási technológiák termelékenységének, a kútkiképzés, szenzor- és monitoring technikák korszerúsítése által, azok magas hômérsékleti és nyomásviszonyokra alkalmas megoldásainak kifejlesztése révén.

3. A hőkinyerés és villamosenergia-termelés optimalizálása, hálózatba integrálása, hibrid rendszerekbe történő integráció.

4. A K+F eredményeken túlmutató környezeti, szabályozói és társadalmi akadályok lebontása európai és globális léptékben.

5. Tudásmegosztás (adatharmonizáció, koordinált adatés információáramlás, megosztott infrastruktúra kiépítése).

Valamennyi fenti témában bíztató hazai eredmények (pl. innovatív kútkiképzési technológiák), komoly poten- 
ciálok, és kiaknázatlan lehetőségek vannak a geotermikus szakmában.

Egy innovatív, robosztus, stimulációs EGS-technológia kifejlesztése a célja az USA és EU kutatók - köztük magyar kutatók - részvételével zajló nemzetközi kutatási együttmúködésnek, mely hatékonyabbá tenné a hőcserélő felület kialakítását és a fluidum cirkulálását (Robust Engineered Geothermal System - REGS). A projekt sikeres laboratóriumi fázisa lezárult, jelenleg a terepi tesztek előkészítése zajlik (DANKO et al. 2019).

A jövőbeli geotermikus projektek felfutása szempontjából a fentiekben említett $\mathrm{K}+\mathrm{F}+\mathrm{I}$ szempontok mellett a befektetôk számára két további fontos aspektus van: a különböző projektek összevethetősége és a kockázatok minimalizálása. Előbbi feladat megvalósítását túzte ki célul az a nemzetközi kutatócsoport, amely az Egyesült Nemzetek Szervezete által kidolgozott ásványvagyon osztályozási módszertan (kódneve: UNFC-2009) geotermikus energiára történő adaptálását végezte el (ECE 2013, EGRC 2014), és amelynek kialakításában, nemzeti esettanulmányok kidolgozásában a hazai kutatók a kezdetektől fogva részt vettek (ECE 2016, 2017). A módszertan felülvizsgálatára 2020-ban került sor (ECE 2020). A UNFC osztályozás alapja egy háromdimenziós rendszer, melynek tengelyei az adott projekt gazdasági-társadalmi életképességét, illetve a szabályozási környezetet és a környezeti aspektusokat (E tengely), a projekt múszaki megvalósíthatóságát (F tengely), valamint a vagyonbecslés megbízhatóságát
(G tengely) jellemzik. A G kategóriák megfeleltethetőek a rezervoár modellezésben is gyakran alkalmazott valószínúségi becslési módszertan (pl. Monte Carlo szimuláció) P90, P50, P10 értékeinek. E tényezők alapján az előzetesen meghatározott (számszerúsített) nyersanyagmennyiség egy háromjegyú kóddal jellemezhető (E, F, G kategóriák), amely nyelvtől és szóhasználattól függetlenül használható bárhol a világon (12. ábra). Az adott kategóriákkal jellemezhetố osztályokba történő besorolás egy megadott időpontra vonatkozik, így az adott E, F, G kategóriák besorolása a projekt életciklusa során (pl. kutatás/kitermelés) értelemszerűen változik. Az elmúlt években több kísérlet is történt a UNFC osztályozási rendszer hazai alkalmazhatóságának tesztelésére (NÁDOR 2016, NÁDOR \& ZILAHI-SEBESS 2016) a frissített módszertan (UNFC-2019) tesztelése jelenleg is zajlik.

A másik fontos kérdéskör, amely a jövőbeli geotermikus projektek számának növekedése szempontjából meghatározó, a geotermikus energia kutatási és kitermelési kockázatainak csökkentése, illetve a fennmaradó kockázatok kezelése. A kockázati elemek (földtani, fúrástechnikai, környezeti, jogi stb.) közül is a legjelentősebb a földtani kockázat, amely a felszín alatti tér ismertségének bizonytalanságából adódik.

Noha Magyarország mélyföldtani és geotermikus viszonyai a több ezer földtani mélyfúrásnak és szénhidrogén-kutató fúrásnak, a közel 1700 aktív, illetve inaktív termálkútnak és azok részletes hidrogeológiai adatainak, a több tízezer $\mathrm{km} 2 \mathrm{D}$ szeizmikus szelvénynek és sok ezer $\mathrm{km}^{2} 3 \mathrm{D}$ szeizmi-

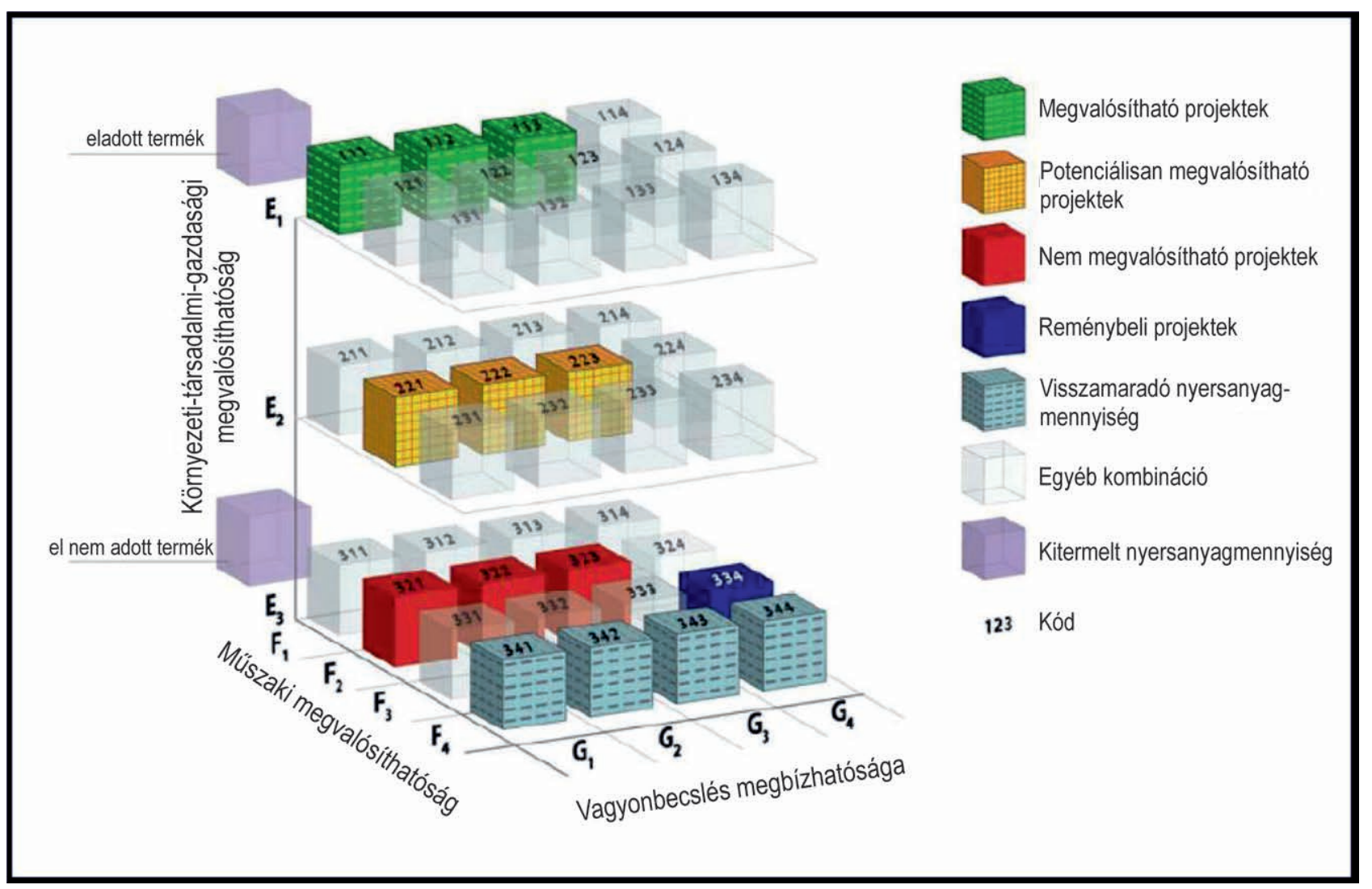

12. ábra. A UNFC-2019 osztályozási rendszer (ECE 2020)

Figure 12. The UNFC-2019 classification scheme (ECE 2020) 
kus adattömbnek, a nagyszámú egyéb geofizikai mérésnek (karotázsok, magnetotellurikus mérések stb.) köszönhetően világviszonylatban is jól ismertnek mondhatók, a geotermikus energia kutatása és kinyerése továbbra is kockázatos tevékenységnek számít. Különösen igaz ez a nagyobb mélységben elhelyezkedő karsztos repedezett tárolók feltárására, ahol a magas hőmérséklet mellett egy nagy permeabilitású törészóna pontos megtalálása is alapvetô a szükséges vízhozamok biztosításához (lásd pl. a sikeres miskolci és győri projektek).

A geotermikus projektek esetén a hosszú (minimum 3050 év) élettartam mellé általában hosszú megtérülési idő tartozik (12-15 év). A magas kezdeti tőkeigényhez (költséges kutatások és mélyfúrások), ugyanakkor alacsony és jól tervezhető múködési költségek tartoznak. A geotermikus kockázatkezelés egyik fő paradoxonja, hogy a kutatási fázis a legdrágább (költséges kutatási módszerek, valamint az elsô mélyfúrás lemélyítése), és kedvezőtlen módon egyben a legkockázatosabb is, hiszen az első kutatófúrás sikerességét kezdetben még nagymértékben befolyásolja a felszín alatti térrész ismeretlen volta. A helyzet hasonló a szénhidrogén kutatáshoz azzal a különbséggel, hogy a sikeres geotermikus projekt esetén is a befektetett tôke megtérülése (ROIReturn on Investment) sokkal lassabb, mint a szénhidrogén esetében, továbbá a befektetô - gyakran a hasznosító maga legtöbbször ezzel az egy projekttel rendelkezik, azaz nincs lehetősége más nyereséges projektekből kitermelni az esetlegesen sikertelen projektbe fektetett összeget. Ezen okok miatt nagy tôkeigényú és magas kockázatú geotermikus projektek kivitelezésébe kevés befektető vág bele, illetve ugyanezen szempontok alapján pénzintézetek sem szívesen nyújtanak hiteleket ilyen projektekhez. Ezen felismerés alapján Európa több országában már sikeresen múködnek geotermikus kockázatkezelő garanciaalapok (BoISSAVY 2020). Múködésük sarokpontja, hogy a biztosítási szerződés megkötésekor a projektfejlesztő és a kockázati alapkezelő/biztosító részletesen rögzítik - több egyéb mellett - a sikeresség/sikertelenség kritériumait és a fedezet mértékét. A biztosítási szerződéskérelmek elbírálása, illetve a konkrét káresemények biztosítási ügyintézése független külsô szakértők tevékenységén alapul, bár az alap múködtetését állami szervek felügyelik. A biztosítási összeg folyósítására akkor kerül sor, ha a fúrás az előzetesen meghatározott technikai paramétereket (elsősorban elvárt hozam és hőmérséklet) nem, vagy csak részben produkálja.

Jelenleg a magyar kormány is megtette az első lépéseket egy ilyen alap felállítására. A hazai geotermikus garanciaalap kezelôi rendszer kialakítása, az ezt támogató szakértői testület felállítása minden bizonnyal az elkövetkezó évek egyik legnagyobb szakmai kihívása lesz. Itt jegyezzük meg, hogy a geotermikus projektek kockázatának nemzeti szintú kezelése először Svájcban merült fel több mint 30 évvel ezelött (RYBACH et al. 1988, RYBACH 2005)!

A geotermikus projektek földtani kockázata nagymértékben csökkenthető a felszín alatti térrész ismeretességének növelésével. Ebben nagy előrelépést jelent a Magyar Bányászati és Földtani Szolgálat munkatársai által 2020- ban elkészített Országos Geotermikus Rendszer (OGRe) amely egységes szerkezetben, egy könnyen kezelhetô és mindenki számára elérhető internetes felületen keresztuil szolgáltat áttekintő léptékú, hiteles és naprakész földtani, vízföldtani, geofizikai információkat, adatokat az ország geotermikus energiavagyonával kapcsolatban magyar és angol nyelven (https://map.mbfsz.gov.hu/ogre). A portál fô részét képezó interaktív webes térképi rendszer alapvetően különböző, ebből a célból speciálisan szerkesztett országos térképek (pl. a legjelentősebb termálvízadó képződmények mélybeli elterjedését határoló földtani szintek, a hőmérsékletviszonyokat jellemző izoterma térképek, a különböző típusú potenciális geotermikus rezervoárok mélybeli elterjedését mutató térképek stb.); pontszerű elemek (pl. hévízkutak, egyéb fúrások, már megvalósult geotermikus projekt helyszínek stb.); illetve területi sokszögek (pl. termálvíztestek, koncessziós területek stb.) halmazából áll, amelyek különböző tematikus rétegcsoportokba rendezve tetszés szerint jeleníthetők meg, illetve egymással kombinálhatók.

\section{Következtetések}

A geotermikus energia megbízható, időjárás-független, helyben rendelkezésre álló, részlegesen megújuló energiaforrás. Használatához jelentős gazdasági és környezeti előnyök társulnak különösen fưtés, hưtés terén. Hazánk energiamérlegében a fưtés-hútési célú energiafelhasználás túlnyomó része, közel 90\%-a földgáz alapú. Mivel Magyarország geotermikus adottságai kiválóak - különösen hidrotermális rendszerek telepítésére - a geotermikus energia fokozott hasznosításával számottevően csökkenthető lenne a földgázimport (KURUNCZI 2017). A mély geotermikus potenciál Magyarországon óvatos becslések szerint is 65-70 PJ/év, míg a sekély mélységú, hőszivattyús technológia további 30-40 PJ/év mennyiségű földhő hasznosítási lehetőségét prognosztizálja (ZILAHI-SEBESS et al. 2012). Ezt összevetve a jelenlegi 6 PJ/év körüli geotermikusenergia-hasznosítással egyértelmúen kijelenthetjük, a hazai fútés-hútés üzletágban a sekély és mély geotermikus energiának kulcsszerepe lehet, amit a Nemzeti Energiastratégia is hangsúlyoz.

A geotermikus energia hordozóközegét jelentô termálvízkészleteink viszont végesek. A termelést csak úgy lehet fenntartható módon fokozni, ha a lehúlt vizet a rezervoárba visszasajtoljuk. Ugyanakkor a geotermikusenergia-felhasználás növelése a jelenlegi hasznosítási hatékonyság javításával, a kaszkád rendszerek elterjesztésével is nagymértékben elősegíthető.

Hazánk földtani adottságai lehetôvé teszik villamosáram-termelő erőmúvek létesítését is, melyek $1 \mathrm{MW}_{\mathrm{e}}$ villamos áram előállítása során kapcsoltan kb. 4-8 $\mathrm{MW}_{\text {th }}$ hôt képesek szolgáltatni. A villamosáram-termelésre alkalmas, 120-130 C-nál magasabb hőmérsékletû hévíztározók zömmel 2500 m-nél mélyebben találhatók, ezek hasznosítása koncesszió keretében lehetséges. Fontos megjegyezni, hogy gazdasági és környezeti értelemben fenntartható geotermikus projekthez három tényezőnek kell együttesen teljesülnie: 
alkalmas földtani, hidrogeológiai adottságok, megfelelő méretû́ és szerkezetű (hő)piac, valamint stabil, kiszámítható gazdasági, jogi környezet. Az elsô kettővel rendelkezünk, míg utóbbi tekintetében még van hová fejlődnünk. Gazdasági szempontból a kockázati alap folyamatban lévő létrehozása jelentősen javíthatja a geotermikus szektor tôkevonzó képességét.

A hazai kutatások eredményessége végső soron a sikeres projektek létrejöttében nyilvánul meg, melynek meghatározó további feltétele a széles körú kivitelezô és szerviz szektor megléte. Sajnos a hazai geotermikának ez a lába sánta. Bár vannak felkészült, fejlődésre képes építő-szolgáltató vállalkozások - melyeknek a bemutatott sikeres projekteket köszönhetjük - a rendszerváltást követően ezen a téren inkább leépülés volt tapasztalható. A hazai geotermikusenergia-potenciál jobb kihasználásához nagy szükség lenne a fúrással, kútkiképzéssel, korszerú üzemeltetéssel foglalkozó, a világ élmezőnyébe tartozó felszíni és felszín alatti technológiákat fejleszteni és alkalmazni képes vállalkozások támogatására. Továbbá egy olyan állami vagy képviseleti joggal felruházott civil szervezetre, mely probléma esetén képes széles körú segítséget nyújtani a geotermikus energiát hasznosítók számára, különösen önkormányzatok esetén. Nagy lehetőség rejlik a szénhidrogén ipar és a geotermikus szektor szorosabb együttmúködésében, fôleg a tapasztalatok átadásában és az adatbázisok összehangolásában. Szerencsére ezen az úton már elindultunk, reményeink szerint jó irányba! Ha már jeles elődeink, korukat megelőzve, Magyarországot Európa geotermikus energiát hasznosító mintaországává tették, ezt az imázst újra kell építenünk.

\section{Köszönetnyilvánítás}

Hálás köszönetünket fejezzük ki RYBACH Lászlónak, LEMBERKOVICS Viktornak és az anonim lektornak, valamint SzTANÓ Orsolya főszerkesztőnek értékes tanácsaikért.

\section{Irodalom - References}

ÁDÁm B., SzAnyi J., Bencsik A., Bozsó G. \& PinJung, Zs. 2019: A decentralizált geotermikus hőellátás és a hőszivattyúzás aktuális kérdései. - Magyar Tudomány 180/12, 1808-1821. https://doi.org/10.1556/2065.180.2019.12.7

ÁDoK J. 2012: Geotermikus fútési rendszerek az önkormányzatok szemszögéből, egy múködő rendszer tapasztalatai. - „A geotermikus alapú távfütô rendszerek elösegítése Európában-GeoDH” projekt nemzeti munkaülése, 2012. december 3., Budapest.

ALFöLDI L. 1965: Budapest hévízkutatási kérdései. - Vízügyi Közlemények 47/3, 304-327.

ALFÖLDI L. 1981: A budapesti geotermikus rendszer áramlási modellje. - Hidrológiai Közlöny 61/9, 397-403.

AlFÖLDI L. \& KAPOLYI L. (szerk.) 2007: Bányászati karsztvízszint süllyesztés a Dunántúli középhegységben. - Magyar Tudományos Akadémia, Földrajztudományi Kutatóintézet, 138 p. ISBN 978-963-9545-15-1

ALMÁSI, I. 2001: Petroleum Hydrogeology of the Great Hungarian Plain, Eastern Pannonian Basin, Hungary. - PhD thesis, University of Alberta, Canada, $312 \mathrm{p}$.

Almási, I. \& SZAnYI, J. 2021: Hydrogeology of the Pannonian Basin. In: Cherry, J. (ed.): The Groundwater Project and eBooks Important Aquifer Systems Around The World. (in press)

ÁRPÁSI M. 1993: Az ország geotermális lehetőségeinek felmérése - különös tekintettel az olajipar érdekeltségére. - Tanulmány, MOL Rt.- OGIL, Budapest, 175 p.

ÁRPÁSI M. 2015: Geovillamos áramtermelés - Forrásoldali lehetőségek Magyarországon. 88 p. https://docplayer.hu/2757779-Arpasimiklos-geovillamos-aramtermeles-a-forrasoldali-lehetosegek-magyarorszagon-2015-majus.html.

Bajcsi, P., Bozsó, T., Bozsó, R. Molnár, G., TÁbor, V., Czinkota, I., M. Tóth, T., Kovács, B., Schubert, F., Bozsó, G. \& Szanyi, J. 2015: New geothermal well-completion and rework technology by laser. - Central European Geology 58/1-2, 88-99. https://doi.org/ $10.1556 / 24.58 .2015 .1-2.6$

BÉLTEKY, L. et al. (szerk.) 1965, 1971, 1977: Magyarország hévízkútjai. - Hévízkútkataszter I-III. VITUKI kiadása, Budapest.

Вовок, Е. 2012: Comparison of geothermal energy production technologies. - Geosciences \& Engineering 1/1, 29-35.

Вовок Е. \& То́тн А. 2007: Geotermikus energiatermelô rendszerek hőveszteségeinek minimalizálása. - OTKA-42785 kutatási zárójelentés.

Вовок Е. \& То́тн А. 2010a: A geotermikus energia helyzete és perspektívái. - Magyar Tudomány. 171/8, 926-936.

Вовок E. \& Tóтн A. 2010b: Túlnyomásos tárolók múvelésének lehetôségei. - Miskolci Egyetem, Gázmérnöki Intézeti Tanszék kiadványa $14 \mathrm{p}$.

Boch, R., Szanyi, J., Leis, A., Mindszenty, A., DeÁk, J., Kluge, T., Hippler, D., Demény, A. \& Dietzel, M. 2016: Geothermal Carbonate Scaling: Forensic Studies Applying High- Resolution Geochemical Methods, - In: [European, Geothermal Energy Council] (szerk.) European Geothermal Congress 2016, Bruxelles, Belgium: European Geothermal Energy Council, Paper: S-GC111, p. 10.

BoISSAVY, C. 2020: Report reviewing existing insurance schemes for geothermal. - GeoRISK project. https://www.georiskproject.eu/wp-content/uploads/2020/02/D3.1_Report-reviewing-geothermal-risk-mitigation-schemes-v2.pdf

BoldizsÁr T. 1967: Terrestrial Heat and Geothermal Resources in Hungary. - Bulletin Volcanologique 30/1, 221-227. https://doi.org/ 10.1007/bf02597670

BoldizsÁr T. \& Gózon J. 1965: A geotermikus energia hasznosítása. - Múszaki Könyvkiadó, 191 p. 
Boncz, L., Sóreg, V., Balázs, E-né, Lux, M., Klemenik, R. B., Krusoczki, T. GY., Pusztai, J., SzÁszfai, J., Tomcsányi, T. \& Milankovics, A. 2013: Zárójelentés a 138. Monor területen végzett szénhidrogén-kutatási tevékenységról. MOL Nyrt. - Kézirat, Magyar Állami Földtani, Geofizikai és Bányászati Adattár, Budapest.

Danko, G., Jobbik, A., Baracza, M. K., Varga, G., Kovacs, I. \& Wittig, V. 2019: Demonstration Tests of a Robust Engineered Geothermal System. - Proceedings, 44th Workshop on Geothermal Reservoir Engineering Stanford University, Stanford, California, February 11-13, 2019 SGP-TR-214

Dobos, I., Marton, L. \& Szlabóczky, P. 2013: History of Hungarian Hydrogeology. - In: Howden, N. \& Mather, J. (eds.) History of Hydrogeology. IAH, CRC Press, 117-125, https://doi.org/10.1201/b12766-11

DomBI, S. 1766: Relatio de minaralibus inclyti comitatus Borsodiensis aquis. - Jelentés a nemes Borsod vármegye ásványvizeiról. Bader Imre Félix kiadása, Bécs.

DöVÉNYI P. 1994: Geofizikai vizsgálatok a Pannon-medence litoszféra fejlődésének megértéséhez. - Kandidátusi értekezés, ELTE Geofizikai Tanszék, Budapest, 120 p.

DövÉNYI, P. \& HoRváth, F. 1988: A review of temperature, thermal conductivity, and heat flow data for the Pannonian Basin. - In: Royden, L. H. \& Horváth, F. (eds): The Pannonian Basin; a study in basin evolution. - American Association of Petroleum Geologists Memoir 45, 195-233.

Dövényi, P., Horváth, F. \& Drahos, D. 2002: Geothermal thermic map (Hungary). - In: Hurter, S. \& HaEnel, R. (eds): Atlas of geothermal resources in Europe. Office for Official Publications of the European Communities (Luxembourg): 267, Publication No. EUR 17811

ECE (Economic Commission for Europe) 2013: United Nations Framework Classification for Fossil Energy and Mineral Reserves and Resources 2009 incorporating Specifications for its Application. - United Nations Publication, ECE Energy Series 42, ISBN 978-92$1-117073-3,2013$.

ECE (Economic Commission for Europe) 2016: Draft Specifications for the application of the United Nations Framework Classification for Fossil Energy and Mineral Reserves and Resources 2009 (UNFC-2009) to Geothermal Energy Resources. -ECE/ENERGY/ GE.3/2016/6 https://www.unece.org/fileadmin/DAM/energy/se/pdfs/egrm/egrc7_apr2016/ECE.ENERGY.GE.3.2016.6_e.pdf

ECE (Economic Commission for Europe) 2017: Application of the United Nations Framework Classification for Resources (UNFC) to Geothermal Energy Resources, Selected case studies. - Energy Series 51. https://www.unece.org/fileadmin/DAM/energy/se/pdfs/ UNFC/UNFC_GEOTH/1734615_E_ECE_ENERGY_110_WEB.pdf

ECE (Economic Commission for Europe) 2020: United Nations Framework Classification for Resources, Update 2019. - Energy Series 125 https://unece.org/DAM/energy/se/pdfs/UNFC/publ/UNFC_ES61_Update_2019.pdf

EGEC 2017, 2018, 2019: Market report

EGRC 2014: Specifications for the Application of the United Nations Framework Classification for Fossil Energy and Mineral Reserves and Resources 2009 (UNFC-2009) to Renewable Energy Resources. - http://www.unece.org/energy/se/unfc_2009.html

ENSZ 2010: Az ENSZ fosszilis energiahordozó- és ásványi nyersanyagkészletre és -vagyonra vonatkozó osztályozási keretrendszere. (Ford: Sári Katalin, 2013). - Kézirat, MFGI adattár, Budapest. https://unece.org/DAM/energy/images/UNFC_Reserv/EGRC/ UNFC_2009_Hungarian.pdf

ERDÉLYI M. 1979: A magyar medence hidrodinamikája. - VITUKI közlemények 18, 82 p.

ERDÉLYI, M. 1985: Geothermics and the deep flow-system of the Hungarian Basin. - Journal of Geodynamics 4, 321-330. https:// doi.org/10.1016/0264-3707(85)90067-5

European Technology and Innovation Platform on Deep Geothermal (ETIP-DG) 2019: Strategic research and innovation agenda Brussels, April 2019. - http://www.etip-dg.eu/front/wp-content/uploads/SRIA_ETIP-DG_web-1.pdf

FöLDEÁKi B. 1972: Súlyos bún, súlyos ítélet. - Szabad Föld, 1972. július-december (28/27-53.) 1972-07-16/29. szám.

HoRVÁTH F. \& BADA G. (szerk.) 2006: A Pannon-medence jelenkori geodinamikájának atlasza: Euro-konform térképsorozat és magyarázó. - Magyar Geofizika 47, 133-137. http://geophysics.elte.hu/atlas/geodin_atlas.htm

Horváth, F., Musitz, B., Balázs, A., Végh, A., Uhrin, A., NÁdor, A., Koroknai, B., Pap, N., Tóth, T. \& Wórum, G. 2015: Evolution of the Pannonian basin and its geothermal resources. - Geothermics 53, 328-352, https://doi.org/10.1016/j.geothermics.2014.07.009

Horváth J., Koroncz P., Fedor F. \& HLATKi M. 2013: Felső-pannon konszolidálatlan homokkövek kôzetfizikai, kôzetmechanikai vizsgálata. - Mérnökgeológia-Közetmechanika, 229-240.

Juhász I., Bányai P., Hamza I., Rman N., Kumelu S., Mozetic S. \& Nádor A. 2013: Hévízhasznosítási helyzetkép a Mura-Zala medence területén a 2009. december 31-i állapotra - A Magyar Állami Földtani Intézet Évi jelentése, 2011, 93-102.

Kalmár, L., Medgyes, T. \& Szanyi, J. 2020: Specifying boundary conditions for economical closed loop deep geothermal heat production. - Energy 196, Publication no. 117068. https://doi.org/10.1016/j.energy.2020.117068

KESSLER H. 1956: A karsztos hévforrások utánpótlásának kérdése. - Hidrológiai Közlöny 2, 127-128.

KIS K. \& FöRGETEG L. 2017: A Szent Erzsébet Mórahalmi Gyógyfürdő helyi gazdaságfejlesztési szerepének értékelése. - Jelenkori társadalmi és gazdasági folyamatok 12/1-2,9-41

Komlós F., Fodor Z., KaPros Z, VAJdA J. \& VASZIL L. 2009: Hốszivattyús rendszerek (Heat Pump Systems). - Magánkiadás, ISBN: 9789630675741, $215 \mathrm{p}$.

KORIM, K., 1972: Geological aspects of thermal water occurrences in Hungary. - Geothermics 1, 96-102., https://doi.org/10.1016/03756505(72)90034-X

Kovács, B., Czinkota, I., Szanyi, J., Bozsó, T., M. Tóth, T. \& Busuttil, L. 2014: The permeability of laser drilled laterals in sandstone reservoirs. - Geosciences and Engineering, 3/5, 83-93.

Kovács Zs. (szerk) 2018: Szénhidrogének Magyarországon. - Magyar Energetikai és Közmú-szabályozási Hivatal, Budapest, 317 p., ISBN 978-615-00-1393-0 
KőRŐSsY L. 1988: A zalai-medencei kőolaj- és földgázkutatás földtani eredményei. - Általános Földtani Szemle 23, 3-162.

KSH 2010: https://www.ksh.hu/docs/hun/xstadat/xstadat_eves/i_fur001a.html

KuRUNCZI M. 2008: A visszasajtolás. A hódmezővásárhelyi geotermikus közmúrendszer bemutatása,. - Geotermia a XXI. században szakmai fórum, Kistelek 2008.

KURUNCZI M. 2017: Hőenergia helyben - Mivel csökkenthető az import földgáz? - Magyar Energetika 2, 18-21.

Lenkey, L., Dövényi, P., Horváth, F. \& Cloetingh, S. A. P. L. 2002: Geothermics of the Pannonian basin and its bearing on the neotectonics. - EGU Stephan Mueller Special Publications Series 3, 1-12. https://doi.org/10.5194/smsps-3-29-2002.

Lenkey, L., ZsEMLE, F., MÁdL-SzŐNYI, J., DöVÉNYI, P. \& RYBACH, L. 2008: Possibilities and limitations in the utilization of the Neogene geothermal reservoirs in the Great Hungarian Plain, Hungary. - Central European Geology 51/3, 241-252. https://doi.org/10.1556/ ceugeol.51.2008.3.6

LENKey L., MihályKa J. \& PARóczi P. 2021: Magyarország geotermikus viszonyainak áttekintése. - Földtani Közlöny, 151/1

LÉNÁRT L. 2019: A termálkarsztot elérő kutak, források és fúrások a Bükk térségben. - Múszaki Földtudományi Közlemények. - A Miskolci Egyetem Közleményei 88/1, 86-93.

LORBERER Á. 2004: Adalékok a hazai hévízkutatás történetéhez. - Felszín Alatti Vizekért Alapítvány, http://www.fava.hu/publikaciok/ jubileumi_kiadvanyok/tanulmanyok_pdf/lorberer_heviz.pdf

Lorberer Á., Dervaderics M. B., Lengyel Z. \& MaGineCZ J. 2008: A Fábiánsebestyén környezetében tervezett termálvíz energetikai hasznosításának földtani megalapozása. - Zárójelentés VITUKI Kht.

Lund, J. W. \& Tотн, A. 2020: Direct Utilization of Geothermal Energy, a Worldwide Review. - Proceedings, World Geothermal Congress 2020, Reykjavik, Iceland, April 26 - May 2, 2020. https://www.geothermal-energy.org/pdf/IGAstandard/WGC/2020/01018.pdf

M. Tóтн T. 2008: Repedezett, metamorf fluidumtárolók az Alföld aljzatában. - MTA Doktori Értekezés, Szeged, 399 p.

Madarász, T., Hartai, É., Kolencsikné Tóth, A., Szúcs, P., Földessy, J., Németh, N., Szanyi, J., Osvald, M., MedGyes, T. \& Kóbor, B. 2019: CHPM2030 - Novel concept of combined heat, power and metal extraction from geothermal brines; - In: European Geothermal Congress 2019; Den Haag, Hollandia Paper 329, 7 p.

MÁDLnÉ SzŐNYI, J. 2006: A Geotermikus Energia - Készletek - Kutatás - Hasznosítás. - Grafon Kiadó, Nagykovácsi, 141 p. ISBN 963218 0585

MÁDL-SZÓNYI, J. \& Tóth, Á. 2015: Basin-scale conceptual groundwater flow model for an unconfined and confined thick carbonate region. Hydrogeology Journal 23, 1359-1380. https://doi.org/10.1007/s10040-015-1274-x

MÁdLNÉ SzŐNYI J., RYBACH L., LENKEY L. \& HÁMOR T. 2008: A geotermikus energiahasznosítás nemzetközi és hazai helyzete, jövóbeni lehetóségei Magyarországon. - MTA, Budapest, 105 p.

Mádlné SzŐnyi J., Erôs A., Havril T., Poros Zs., Győri O., Tóth Á., Csoma A., Ronchi P. \& Mindszenty A. 2018: Fluidumok, áramlási rendszerek és ásványtani lenyomataik összefüggései a Budai Termálkarszton. - Földtani Közlöny 143/1, 75-96. https://doi.org/ 10.23928/foldt.kozl.2018.148.1.75

Maros, G., Albert, G., Szeiler, R. B., Fodor, L., Gyalog, L., Jocha-Edelényi, E., Kercsmár, Zs., Magyari, Á., Maigut, V., Maros, G., NÁdor, A., Orosz, L., PAlotás, K., Selmeczi, I., Uhrin, A., Vikor, Zs., Atzenhofer, B., Berka, R., Bottig, M., Brüstle, A., Hörfarter, C., Schubert, G., Weilbold, J., Baráth, I., Fordinál, K., Kronome, B., Maglay, J., Nagy, A., Jelen, B., Lapanje, A., Rifelj, H., Rižnar, I. \& Trajanova, M., 2012: Summary Report of the Geological Models Transenergy Project. 189 p. (http://transenergy-eu.geologie.ac.at/).

MARTON L. 1982: Izotóphidrológiai modellek és számítási eljárások a felszín alatti vizek mozgásának tanulmányozásához. - Hidrológiai Közlöny 12, 525-533.

MEKH 2020: Geotermikus Budapest. - 125 p. ISBN 978-615-6137-00-5

MEGYeRY M. 1974: Vízbesajtoló kutak áramlástani vizsgálatainak tapasztalatai. - Bányászati és Kohászati Lapok. Köolaj és Földgáz 7 (107) 8, 237-243.

MTA, MMK, MATÁSZSZ. MTT 2015: Települési hőellátás helyi energiával címú konferencia állásfoglalása. - Energiagazdálkodás 56/5-6, 65-66.

NÁDOR A. 2016: A geotermikus energiavagyon nemzetközi osztályozási és jelentési rendszerei és a hazai adaptáció első lépései. Földtani Közlöny 146, 123-134

NÁDOR, A. (ed.), 2019: Cascades and calories: geothermal energy in the Pannonian Basin for the 21 st century and beyond. - Faculty of Mining and Geology, Belgrade University (Belgrade) $130 \mathrm{p}$.

NÁDOR, A. \& ZILAHI-SEBESS, L. 2016: Entering geothermal energy into the UNFC-2009 classification system: case studies of direct-use projects from Hungary. - Extended abstracts, Proceedings, European Geothremal Congress 2016, Strasbourg, France, 19-24 September, 2016.

Nádor, A., Lapanje, A., Tóth, Gy., Rman, N., Szőcs, T., Prestor, J., Uhrin, A., Rajver, D., Fodor, L., Muráti, J. \& Székely, E. 2012 : Transboundary geothermal resources of the Mura-Zala basin: a need for joint thermal aquifer management of Slovenia and Hungary - Geologija 55/2, 209-224. https://doi.org/10.5474/geologija.2012.013

NÁdor, A., KujBus, A. \& Tóth, A. 2019a: Geothermal energy use, country update for Hungary. Extended abstracts, Proceedings, European Geothermal Congress 2019, Den Haag, The Netherlands, June 11-14, 2019.

Nádor, A., Zilahi-Sebess, L., Rotár-Szalkai, Á., Gulyás, Á. \& MARKovic, T. 2019b: New methods of geothermal potential assessment in the Pannonian basin. - Netherlands Journal of Geosciences 98, e10. https://doi.org/10.1017/njg.2019.7

NÁdor A., Gulyás Á. \& Maigut V. 2020: Országos Geotermikus Rendszer (OGRe) - Felhasználói kézikönyv. https:/l map.mbfsz.gov.hu/ogre/melleklet/kezikonyv_hu.pdf

Osvald, M., SzAnyi, J., Medgyes, T. \& KóBOR, B. 2017: Geothermal energy developments in the district heating of Szeged. - European Geologist 43, 30-33. 
Osvald, M., Kilpatrick, A. D., Rochelle, C. A., Szanyi J., Medgyes T. \& Kóbor B. 2018: Laboratory Leaching Tests to Investigate Mobilisation and Recovery of Metals from Geothermal Reservoirs, - Geofluids Special issue, Article ID 6509420, 1-24. https://doi.org/10.1155/2018/6509420

REZESSY G., SZANYI J. \& HÁMOR T. 2005: Jelentés a geotermikus energiavagyon állami nyilvántartásának kialakításáról. - Kézirat, MGSZ, Budapest, 85 p.

Rman, N., Gal, N., Marcin, D., Weibold, J., Schubert, J., Lapanje, A., Rajver, D., Benková, K. \& Nádor, A. 2015: Potentials of transboundary thermal water resources in the western part of the Pannonian basin - Geothermics 55, 88-98. https://doi.org/ 10.1016/j.geothermics.2015.01.013

Rman, N., Bălan, L.L., BobovečKi, I., Gál, N., Jolović, B., Lapanje, A., Marković, T., Milenić, D., Skopluak, F., Rotár Szalkai, Á., Samardžıć, N., Szőcs, T., Šolaja, D., ToholJ, N., Vijdea, A. M. \& VranjeŠ, A. 2020: Geothermal sources and utilization practice in six countries along the southern part of the Pannonian basin. - Environmental Earth Sciences 79/1, Article number: 1 (2020), https://doi.org/10.1007/s12665-019-8746-6

Rotár-Szalkai, Á., Nádor, A., Szőcs, T., Maros, Gy., Goetzl, G. \& ZeKIri, F. 2017: Outline and joint characterization of transboundary geothermal reservoirsat the western part of the Pannonian basin. - Geothermics 70, 1-16. https://doi.org/10.1016/ j.geothermics.2017.05.005

Rotár-Szalkai, Á., Maros, Gy., Bereczki, L., Markos, L., Babinszki, E., Zilahi-Sebess, L., Gulyás, Á., Kun, É., Szốcs, T., Kerékgyártó, T., Nádor, A., Rajver, D., Lapanje, A., Šram, D., Marković, T., Vranješ, A., Farnoaga, R., Samardžić, N., HrVATOVIĆ, H., SKOPLJAK, F. \& JolOVIĆ, B. 2018: Identification, ranking and characterization of potential geothermal reservoirs. Report of the DARLINGe project: 82 p. https://www.interreg-danube.eu/approved-projects/darlinge/outputs

RYBACH, L. 2005: Die Schweizer Risikodeckung für Geothermiebohrungen - Ausgestaltung und Erfahrungen. - In: Geothermische Jahrestagung 2005 «Geothermie: Synergie und Effizienz»-Tagungsband Geothermische Vereinigung e.V., 16-17. November 2005, Unterschleissheim/D, 18-23. ISBN 3-932570-53-7

RYBACH, L. 2010: "The Future of Geothermal Energy" and its Challanges. - Proceedings World Geothermal Congress 2010, Bali, Indonesia, 25-29 April 2010, http://globalatlas.irena.org/UserFiles/Publication/The\%20future\%20of\%20Geothermal\% 20Energy\% 20 and\%20Challenges.pdf

RYBACH L. 2019: A geotermikus energia helyzete világszerte. - Magyar Tudomány 180/12, 1760-1771. https://doi.org/10.1556/ 2065.180.2019.12.2

RYBACH, L. \& STEGENA, L. (eds) 1979: Geothermics and Geothermal Energy. - Springer Basel AG, 341 p. ISBN 978-3-0348-6525-8

Rybach, L., FeHr, A. \& RouX, D. 1988: The Swiss system of governmental risk coverage for geothermal drilling. - In: Communications/Proceedings JIGASTOCK 1988, Paris, 1, 19-21.

SzANYI J. 2015: Felszín alatti vizek mennyiségi állapotának meghatározása, 6-5-2 háttéranyag, Az alföldi termál víztesteken kialakult süllyedések szakértői elemzése. - Vígyújtő gazdálkodási Terv 2015. (http://vizeink.hu/).

SZANYI, J. \& KovÁCS, B., 2010: Utilization of geothermal systems in South-East Hungary. - Geothermics, 39, 357-364. https://doi.org/ 10.1016/j.geothermics.2010.09.004

SzAnYI, J., KovÁcs, B. \& SchareK, P. 2009: Geothermal Energy in Hungary: potentials and barriers. - European Geologist 27, 15-19.

SzAnYI, J., Kurunczi, M., KóBor, B. \& Medgyes, T. (szerk.) 2013: Korszerú technológiák a termálvíz visszasajtolásban: Kutatási eredmények és gyakorlati tapasztalatok. - InnoGeo Kft. Szeged, Magyarország, 202 p.

Szanyi, J., Osvald, M., Medgyes, T., Kóbor, B., M. Tóth, T., Madarász, T., Kolencsikné Tóth, A., Debreczeni, Á., Kovács, B., VÁsÁRHELYI, B. \& B. ROZGONYI-BoISSINOT, N. 2017: Fracture enhancement in structures using a variety of laboratory experiments, In: Recommendations for Integrated Reservoir Management: CHPM2030 Deliverable D2.1 41-68.

SzETÁv Kft. 2019: Épülő Szegedi Geotermikus távhő rendszer vázlatrajza a tervezett kutak és hőközpontok helyének feltüntetésével https://www.szetav.hu/rolunk/projektjeink.html

SzITA G. 2014: Geotermikus gyorsítás Veresegyházon. - Elöadás, MMK Geotermikus Szakosztály Szakmai Nap - 2014. május 29. http://geotermia.lapunk.hu/tarhely/geotermia/dokumentumok/201406/szitagabor_eloadasa_20140529.pdf

Szőcs, T., Rman, N., Rotár-Szalkai, Á., Tóth, Gy., LApanje, A., CERnAK, R. \& NÁdor, A. 2018: The upper pannonian thermal aquifer: Cross border cooperation as an essential step to transboundary groundwater management. - Journal of Hydrology: Regional Studies 20, 128-144. https://doi.org/10.1016/j.ejrh.2018.02.004

SzŐKE Sz. 2016: Veresegyház: új termelő kút, új fogyasztók. - Földhő Hírlevél 52-53, 8-9.

Szứcs P., Fejes Z., ZÁKÁnyi B., FeKete Zs., SzÁrnya G., Hartai É., Turai E., Gyulai Á., Szabó N. \& Cserny T. 2014 : Ásvány-, gyógyés hévizek a Tokaji-hegységben. - In: A Kárpát-medence ásványvizei X. Nemzetközi Tudományos Konferencia, Csíkszereda; 32-39. ISBN: 978-973-7625-63-2;

Tester, J. W., Anderson, B. J., Batchelor, A. S., Blackwell, D. D., DiPippo, R., Drake, E. M., Garnish, J., Livesay, B., Moore, M. C., Nichols, K., Petty, S., Toksoz, M. N. \& Veatch, R. W. 2006: "The Future of Geothermal Energy: Impact of Enhanced Geothermal Systems (EGS) on the United States in the 21st Century.” - Cambridge, MA, INL/EXT-06-11746.

THAN K. 1890: Az ásványvizeknek chemiai constitutiójáról és összehasonlításáról. - Értekezések a természettudományok köréból $20 / 2,1-47$.

Tóтн A. 2016: Magyarország geotermikus felmérése. - A Magyar Energetikai és Közmú-szabályozási Hivatal, Budapest, 2. kiadás, 179 p. ISBN 978-963-12-7712-8.

Tóтн Gy. 2017: A Hévízi-tó vízgazdálkodási helyzete. - Balatoni Részvízgyújtô Vízgazdálkodási Tanács ülése 2017. május 10. http://vpf.vizugy.hu/reg/kdtvizig/doc/Heviz_vizgazdalkodasi_helyzet_2017_05_10_TGy.pdf

Tóth Gy., Horváth I., Muráti J., Rotárné Szalkai Á., Szôcs T. \& Vetô I. 2010: XL Pannon hidrogeológiai modell fejlesztése és lehetőségei a vízgyưjtő gazdálkodásban. - XVII Konferencia a felszín alatti vizekról. Siófok 2010 március 24-25. http://www.fava.hu/ siofok2010/eloadasok/1nap/1115_tothgy_horvathI_muratij_rotarnesza_szucst_vetoI.pdf 
Tóth, Gy., Rman, N., Rotár-Szalkai, Á., KeréKgyÁrtó, T., SzŐcs, T., Lapanje,A., ČERnák, R., Remsík, A., Schubert, G. \& NÁdor, A. 2016: Transboundary fresh and thermal groundwater flows in the west part of the Pannonian Basin. - Renewable and Sustainable Energy Reviews, 57, 439-454. https://doi.org/10.1016/j.rser.2015.12.021

То́тн J. 1963: A Theoretical Analysis of Ground-Water Flow in Small Drainage Basins. - Journal of Geophysical Research 68/16, 4795-4812.

TóтH, J. \& ALMÁSI, I. 2001: Interpretation of observed fluid potential patterns in a deep sedimentary basin under tectonic compression: Hungarian Great Plain, Pannonian Basin. - Geofluids 1/1, 11-36. https://doi.org/10.1046/j.1468-8123.2001.11004.x

Varga, A., Bozsó, G., Garaguly, I., Raucsik, B., BencsiK, A. \& KóBor, B. 2019: Cements, Waters, and Scales: An Integrated Study of the Szeged Geothermal Systems (SE Hungary) to Characterize Natural Environmental Conditions of the Thermal Aquifer. Geofluids Special issue, Article ID 4863814. https://doi.org/10.1155/2019/4863814

VARGa, G., Fiser-Nagy, Á. \& FAnCSIK, T. 2020: Analysis of time-dependent filtration utilising measurements made on sandstone samples. - European Geologist Journal 46, 24-29.

VASS, I., M. Tóth, T., SZANYI, J. \& KovÁCS, B. 2018: Hybrid numerical modelling of fluid and heat transport between the overpressured and gravitational flow systems of the Pannonian Basin. - Geothermics 72, 268-276. https://doi.org/10.1016/j.geothermics. 2017.11.013

Zilahi-sebess L., Merényi L., Gulyás Á., Paszera Gy., Tóth Gy., Boda E. \& Budai T. 2012: Nemzeti Energiastratégia, Készletgazdálkodási és hasznosítási cselekvési terv. - Nyersanyag készletek, A hazai ásványi nyersanyag-potenciál, 5. Geotermikus energia. Kézirat Háttértanulmány. Magyar Földtani és Geofizikai Intézet, 84 p.

Zsigmondy V. 1865: Bányatan kiváló tekintettel a kôszénbányászatra. Elsó rész. [unicus]: A kutatás, fúrászat, s az artézi kutak. - Pest, Osterlamm Károly bizománya, 182 p.

ZsigmONDY V. 1871: Tapasztalataim az artézi szökőkutak fúrás körül. - Pest, Hoffmann és Molnár, 46 p.

ZsIGMONDY V. 1874: A Buziási gyógyfürdő és az ott legújabban véghezvitt fúrások. - Földtani Közlöny 6-7, 159-170.

ZsigmondY V. 1879: A városligeti artézi kút Budapesten. - Földtani Közlöny 9, 128-131.

Kézirat beérkezett: 2020.09. 04. 